\title{
Cenozoic ecological history of South East Asian peat mires based on the comparison of coals with present day and Late Quaternary peats
}

\author{
Robert J. MORLEY $Y^{1,2,3^{*}}$ \\ ${ }^{1}$ Department of Earth Sciences, Royal Holloway University of London, Egham, Surrey TW20 0EX; ${ }^{2}$ Palynova Ltd., 1 Mow Fen \\ Road, CB6 1PY Littleport, UK; ${ }^{3}$ NIKO Asia Ltd., J1 Kemang Timur 22, 12510 Jakarta, Indonesia \\ *Corresponding author: pollenpower@palynova.com
}

\begin{abstract}
Tropical peat swamps are more widespread in Sundaland than in any other equatorial region. Also, Cenozoic deposits from the area are rich in coals. The developmental pattern of present day peat swamps from the region has often been used to help clarify that of coals in the geological record. This paper initially reviews the ecology of present day ombrotrophic, rheotrophic and brackish mangrove peat swamps, and their pattern and timing of development during the Holocene and latest Pleistocene based on palynological studies. Then, it attempts to examine the developmental pattern of the peats which led to the formation of Cenozoic coals across the region, based on both published and unpublished datasets generated during the course of hydrocarbon exploration programmes. It is concluded that Cenozoic coals reflect a greater variety of peat forming settings than occurs in the region today. Extensive brackish water peats formed during the Middle and Late Eocene and Middle and Late Miocene, these often being laterally very extensive. Rheotrophic peats also formed widely through most of the Cenozoic. Ombrotrophic kerapah type peats are first recognised in the Late Oligocene, based on their content of common Casuarina type and Dacrydium pollen, and were particularly common during the Early and Late Miocene in the Sunda shelf region. Kerapah peats sometimes developed great thickness. Basinal peats, on the other hand, increased in representation during the course of the Miocene. No convincing evidence for doming in Cenozoic peats has yet been noted, but on the other hand, no really thick coals, which may have been formed from basinal peats, have so far been studied. As a consequence, examples of doming in the rock record from this area are probably yet to be found.
\end{abstract}

Key words: ombrotrophic kerapah mires, basinal peat mires, rheotrophic peats, Southeast Asia, Cenozoic coals.

Received: February 2013. Accepted: June 2013.

\section{INTRODUCTION}

The occurrence of widespread peat swamps along the east coast of Sumatra was brought to attention by Koorders (1895). Koorders considered these swamps to be present day analogues of the peat swamps which led to the formation of carboniferous coals. Geomorphological and ecological studies from Sumatra by Polak (1933, 1950) and from Sarawak/Brunei by Anderson (1963, 1964) subsequently demonstrated that many peat swamps were dome-shaped, and hence ombrotrophic (i.e. they receive their water and nutrients from precipitation only). The doming is also clearly reflected in their vegetation, which is generally organised into concentric zones, characterised both floristically and physiognomically, with vegetation attaining smaller stature and reduced diversity, which are thought to reflect a gradient of increasing oligotrophication and reduced nutrient availability from the margins to the centre of each dome. These catenas were demonstrated to reflect true temporal successions from palynological studies (Anderson and Muller, 1975), with Sarawak peats accumulating mostly since sea levels became stabilised during the mid-Holocene, about 5000 years ago.
The analogy between these peats and the peats which formed the Carboniferous coal measures has since been strengthened through the demonstration that the vegetation which formed Carboniferous peats also exhibited a temporal vegetation succession, which is reflected by palaeobotanical data (Eble and Gaudy, 1990; Pierce et al., 1991; Rupert et al., 1991) and in successional variations of coal macerals (Gaudy and Eble, 1990).

The Southeast Asian region is rich in coal deposits of Cenozoic age, and a logical progression was to examine such coals for analogous temporal successions. Initial studies from Brunei by Anderson and Muller (1975) clearly demonstrated that a peat which formed a Miocene coal bore a vegetation which was floristically and ecologically very similar to that observed in the initial stage of the succession within present day Sarawak peat swamps, but up to now, no convincing evidence for the concentric zoning, or of temporal successions comparable to that seen either in present day peat swamp vegetation, or in Holocene peats, has been brought to attention with respect to Cenozoic coals.

It has been suggested that ombrotrophic peats are the main source of coals in the geological record (Clymo, 
1987). However, this review suggests that coals may have formed from ombrotrophic and rheotrophic (i.e. receiving water and nutrients mainly from groundwater or rivers) freshwater and brackish water peats.

Our present day knowledge of peat-forming vegetation in Southeast Asia shows that there are many regional differences, and also that peats form in a variety of geomorphological settings, depending on topography, soils, salinity and climate. This review initially compares the different types of peat-forming vegetation which are recorded from Southeast Asia, and pays particular attention to evidence for temporal successions within such vegetation types, which can be supported from palynological studies. The second part of the review examines palynological evidence for the nature of Cenozoic peat swamp vegetation from the palynological study of coals, and pays attention on the one hand to the changing character of peat-forming vegetation through time, and on the other hand, to evidence for temporal vegetational successions within coals which might reflect the concentric zoning or doming recorded within some present day peat mires.

\section{METHODS}

The first part of this review is based on published ecological studies of southeast Asian peat swamps, and Quaternary palynological records, whereas the second part utilises palynological studies of coals, using partly pub- lished and partly unpublished data generated during the course of petroleum exploration, based on analysis of conventional cores and cuttings from petroleum exploration wells. Palynological data from Cenozoic deposits have been examined using the same methods as for Quaternary peats, allowing judgments to be made as to whether Cenozoic peat forming environments were similar or different to those of the Quaternary.

\section{PRESENT DAY AND HOLOCENE PEAT-FORMING VEGETATION IN SOUTHEAST ASIA}

Peat formation in Southeast Asia may occur in areas of high rainfall, with the absence of a dry season (Morley, 1981a, 1981b), either in the form of ombrotrophic blanket bog type mires, which are maintained wholly by rainfall, and are believed to be highly oligotrophic, and covered by dense forests, or in rheotrophic, topogenous mires, with topographic factors retarding drainage, in which case they may be either oligotrophic or eutrophic and bear either forest, or herbaceous marsh (Fig. 1). Ombrotrophic peat-forming mires are particularly widespread in coastal regions, where they often attain large size, but also occur widely inland, and also form locally in mountainous regions. Rheotrophic mires have been much less studied and are little-understood. Some are very extensive, such as the Berbak swamp in Sumatra; however, most are of limited

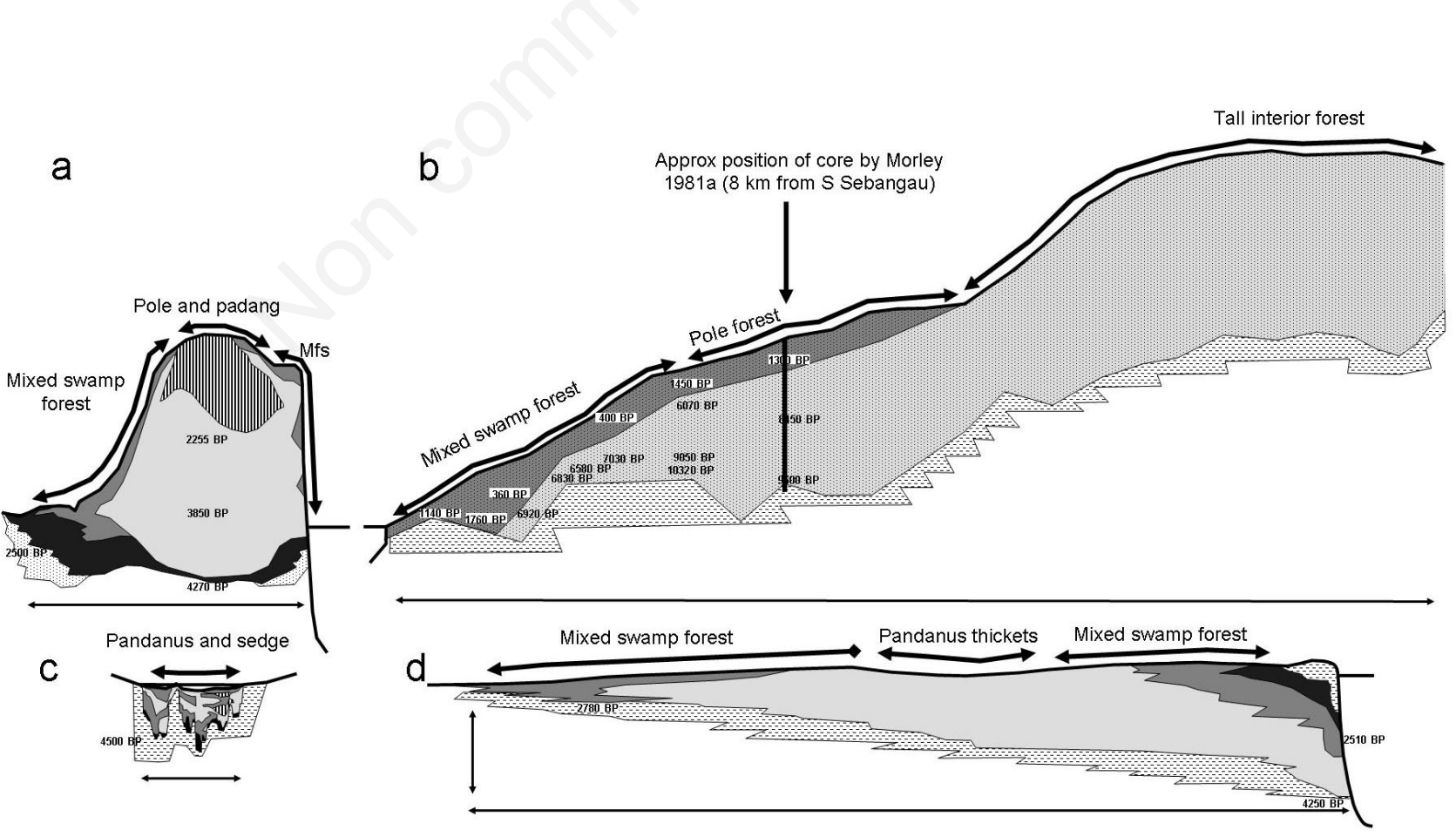

Fig. 1. Peatswamp profiles at the same scale. Ombrotrophic: a) Marudi, Sarawak; b) Sebangau, Kalimantan Tengah. Rheotrophic: c) Tasek Bera, West Malaysia; d) Berbak swamp Jambi, Sumatra. a,d) Peat profiles from Esterle and Ferm (1994); b) from Page et al. (2006); c) from Bastin and Wurst (2002). The Sebangau profile is $25 \mathrm{~km}$ long. 
geographical extent. They are also common in mountainous regions. As will be clear from the following text, peats may form in settings which are intermediate between the rheotrophic and oligotrophic extremes. Peats also sometimes form within coastal mangroves.

\section{Ombrotrophic swamp vegetation}

There are two main types of freshwater ombrotrophic peat-forming forest within the lowlands of the Southeast Asian region, and a comparable type within montane regions, each characterised by extreme waterlogging, low levels of mineral nutrient availability and tea-coloured, very acid water, the two divisions first being recognised by Brunig (1974). These are: basinal peats, growing behind mangrove swamps [the coastal domed peats were initially studied by Anderson (1963)], and kerapah or watershed peats (Morley, 2000) which mainly form inland. Brunig (1990) termed the lowland types as coastal, or deltaic peat swamp forest and kerapah forest (the local Sarawak name for such forests), which is the waterlogged variant of kerangas, or heath forest. Andriesse (1974) suggested the term basinal for the former type, which is preferred here, since such peats may not be restricted to deltas, and also kerangas peats may occur in coastal locations. Basinal peats are described in detail by Anderson (1963, 1964, 1983). Sieffermann et al. (1992) suggested the name high peats for inland peats in South Kalimantan, a term which does not capture the wide variation seen in this peat swamp type, and so the term kerapah/watershed peat is preferred (Morley, 2000). Brunig (1974, 1990) outlined the main features of kerapah peats from Sarawak. The Sarawak valley peat swamps of Andriesse (1974) are probably a variant of kerapah peats.

\section{Basinal peats}

Basinal peat swamp forests (Figs. 1a and 2A) principally develop along relatively stable or subsiding, prograding coastlines in areas previously occupied by mangrove swamps (e.g. Caline and Huang, 1992), or extend along lowland river valleys in areas such as South Kalimantan (Sieffermann et al., 1992) and Central and South Sumatra (Supiandi, 1990). These peat swamps developed following stabilisation of sea levels around 6000 years ago (Dommain et al., 2011), and are thus closely tied to the cycle of eustatic sea level change (Morley, 1996). They have yielded basal radiocarbon dates varying from 6000 to 1100 years before the present (bp) (Dommain et al., 2011). These forests are characterised by concentrically zoned vegetation and may grow on deep peat, up to $20 \mathrm{~m}$ thick. Basinal peats are widely developed in Sarawak/Brunei, West Sumatra, West and South Kalimantan. The manner in which peat formation commences has been variously discussed (Anderson, 1964; Esterle and
Ferm, 1994), but Gastaldo (2010) demonstrated that peat formation is determined mainly by the mineralogy of the substrate, with peats forming when the underlying clays consist of mixed layer and expandable clays, restricting pore water flow in the tidal and overbank deposits, and forming an aquiclude, above which paludal conditions develop, promoting accumulation of organic matter.

Although the character of both basinal peat swamp and kerapah forests in Sarawak and Brunei has been known for some time, the extent to which these are representative of peat-forming swamps on a more regional basis, and the timing of peat formation, is only just becoming clear. Anderson (1963, 1964) differentiated the basinal peat swamps in Sarawak/Brunei into six phasic communities, along a gradient, or catena, of decreasing soil fertility and increasing waterlogging, from the periphery to the centre of mires. The structure of Sarawak swamps and representation of phasic communities is strongly influenced by the presence of one dominant species, Shorea albida (Dipterocarpaceae), which is absent from swamps outside Sarawak, western Brunei and northwest Kalimantan. The importance of this species in phasic community characterisation in Sarawak needs to be given close attention when making comparisons to areas outside the range of $S$. albida.

With respect to mixed swamp forest from Sarawak/Brunei, phasic community (ph.) 1 (Figs. 2A and 3a) occurs around the perimeter of mires, and according to Anderson (1983) shows many similarities with lowland rain forest in terms of physiognomy, being floristically diverse, structurally complex, multistoreyed, mesophyllous forest, and floristically with some kerangas communities (Brunig, 1990); the dominant species are Gonystylus bancanus (Gonystylaceae), Copaifera palustris (Leguminosae), Dactylocladus stenostachys (Crypteroniaceae) and some dipterocarps, such as Shorea uliginosa and Dryobalanops rappa (but excluding $S$. albida). Ph. 2 shows many similarities to ph. 1, but is of reduced diversity, with Shorea albida well represented among the canopy and emergent trees, and with Stemonurus secundiflorus (Icacinaceae) and Gonystylus bancanus characteristic of the canopy and understorey, whereas ph. 3 is composed almost exclusively of very large specimens of Shorea albida, with very poor development of the understorey (Figs. 2A, 3b and 4a). The leaf-size spectrum of the canopy changes within ph. 3 from mesophyll to mesophyll/notophyll, and with leaves becoming more sclerophyllous and xeromorphic. Ph. 4 and 5 lack emergent size trees, and consist of very dense notophyllleaved pole forests (Figs. 2A and 3c). Dominants are Tristania spp. (Myrtaceae), Parastemon spicatum (Rosaceae), Palaquium cochlearifolium (Sapotaceae) and Combretocarpus rotundatus (Rhizophoraceae) with Shorea albida present only in ph. 4. Within the notophyllous to microphyllous open woodland or savanna of ph. 6 (Figs. 2A and $3 \mathrm{~d})$, Combretocarpus rotundatus is the only significant tree 
species, but shrubs (mainly of species which attain tree status in other phasic communities), and herbs are common (especially myrmecophytes and insectivorous plants).

Palynological studies by Anderson and Muller (1975) demonstrated that the succession seen in the catena is a true temporal succession, developing over the last 5000 years, since sea levels stabilised during the mid Holocene (Fig. 5), although they experienced difficulties in differentiating ph. 2 from 3 , and 5 from 6 . The earlier phases ( 1 and 2 ) were clearly differentiated by the presence of regular pollen of the trees Blumeodendron (Euphorbiaceae), Campnosperma (Anacardiaceae), Gonystylus, Lophopetalum multinervium (Celastraceae), Stemonurus, and common spores of the fern Stenochlaena palustris (Blechnaceae), whereas the more advanced phases (ph. 4-6) were characterised by the presence of common Combretocarpus rotundatus, Parastemon, Dactyocladus, and herbs, such as Cyperaceae and Nepenthes (Nepenthaceae). They note rare specimens (less than 1\%) of mangrove pollen, and Dacrydium (Podocarpaceae) and Casuarina (Casuarinaceae) within several samples, but they interpret these as being blown in from outside the swamp.

Outside Sarawak and Brunei, in areas without Shorea albida, the catena is simpler, with ph. 2, 3 and 4 being absent, although substantial interstand variation may occur within the same phasic community. Evidence for concentric zoning is clear in Sumatran, South Kalimantan and some West Malaysian swamps (Anderson, 1976, 1983; Esterle and Ferm, 1994), and in these areas, two, or pos-
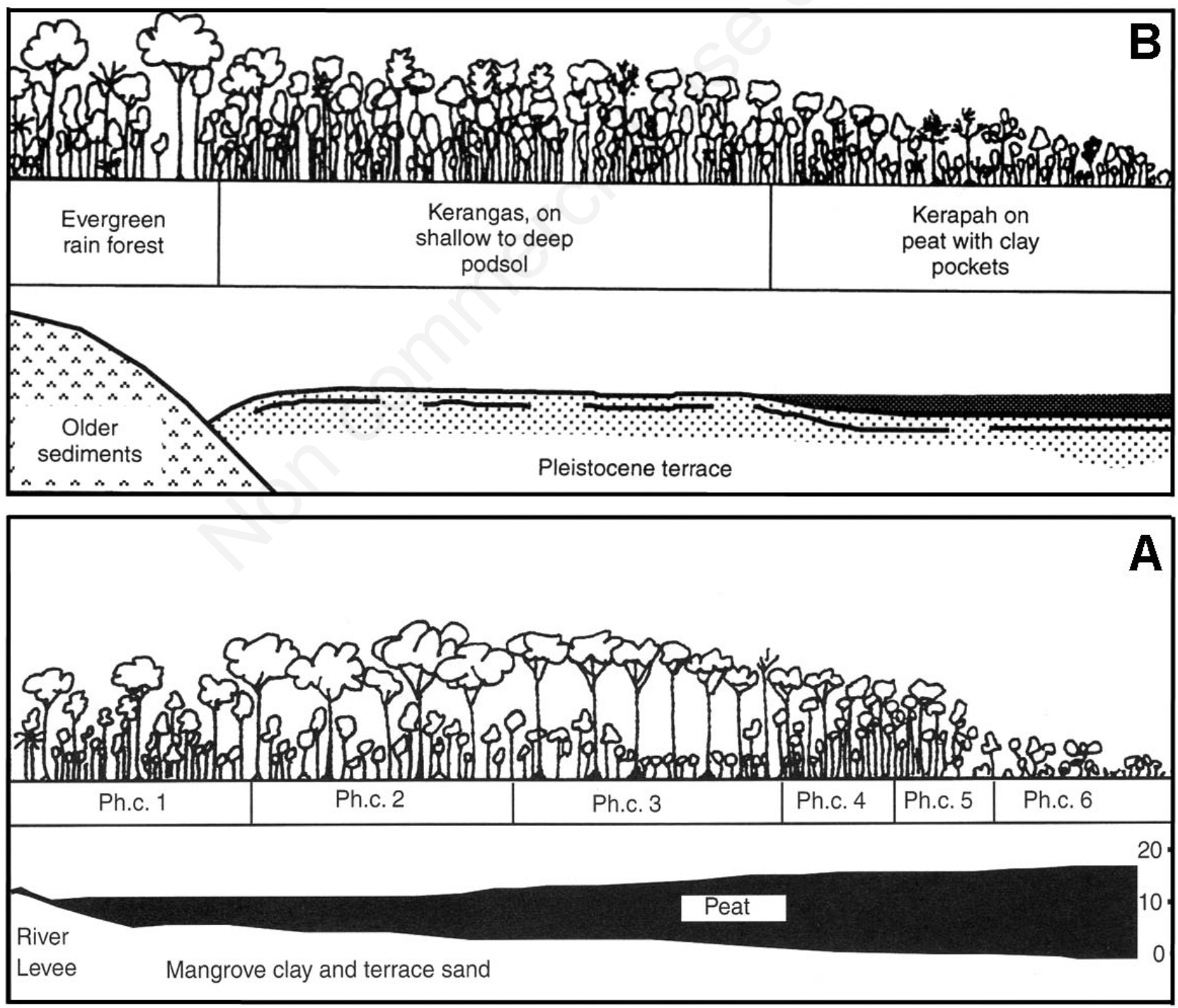

Fig. 2. Basinal (A) and kerapah (B) peat swamp catena compared [from Morley (2000)]. 

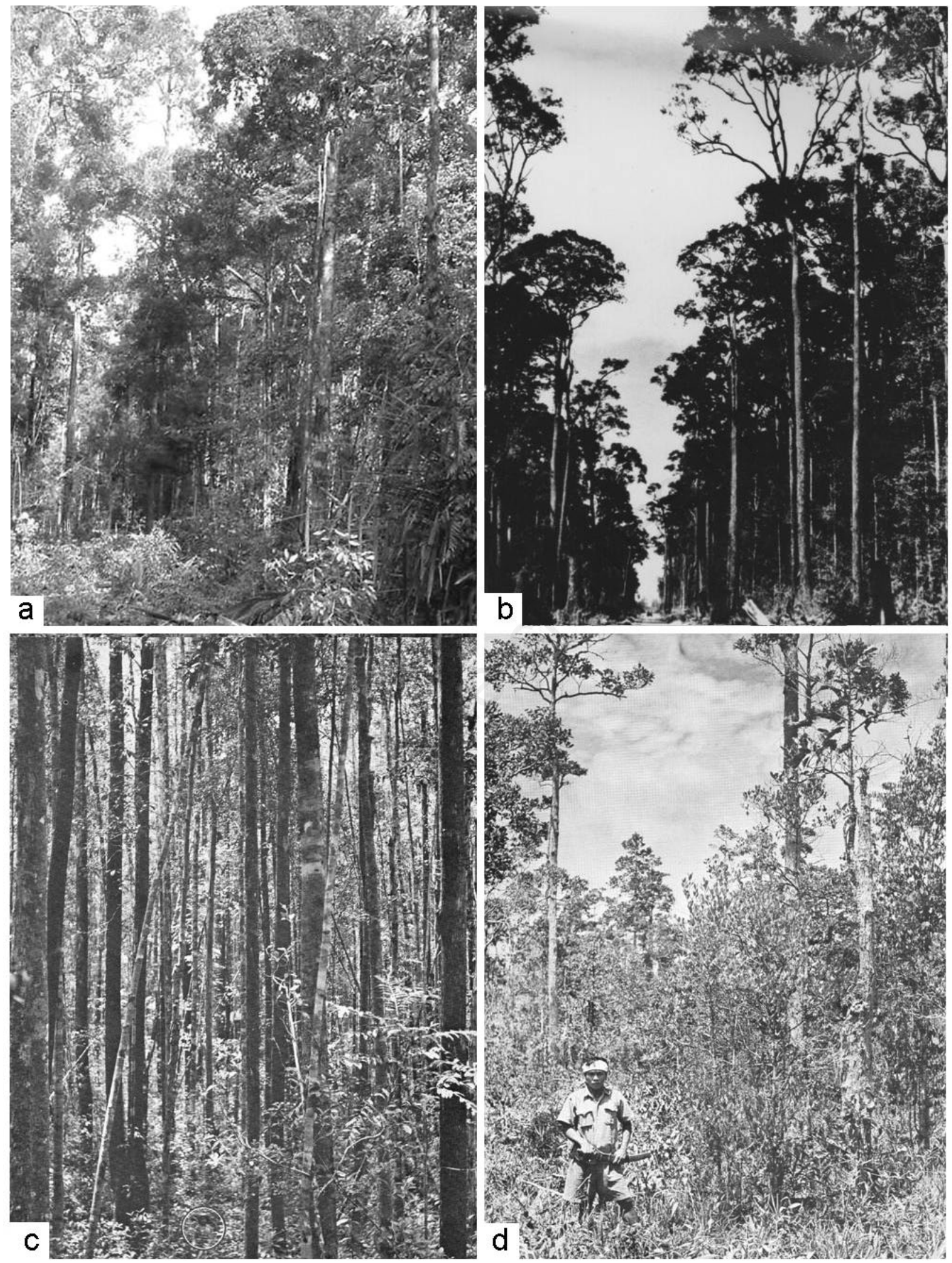

Fig. 3. Photographs of basinal peat swamp forests: a) mixed swamp forest (ph. 1), Pekan, West Malaysia, with Gonystylus bancanus and Calophyllum spp. dominant; b) Alan Bunga forest (ph. 3), with Shorea albida dominant, Brunei (photo by P.S. Ashton); c) Padang Alan, pole forest (ph. 4), Sarawak, Shorea albida dominant [from Whitmore (1975) (courtesy of J.A.R. Anderson)]; d) Padang Keruntum (ph. 6), Sarawak, Combretocarpus rotundatus dominant [from Whitmore (1975) (courtesy of J.A.R. Anderson)]. 

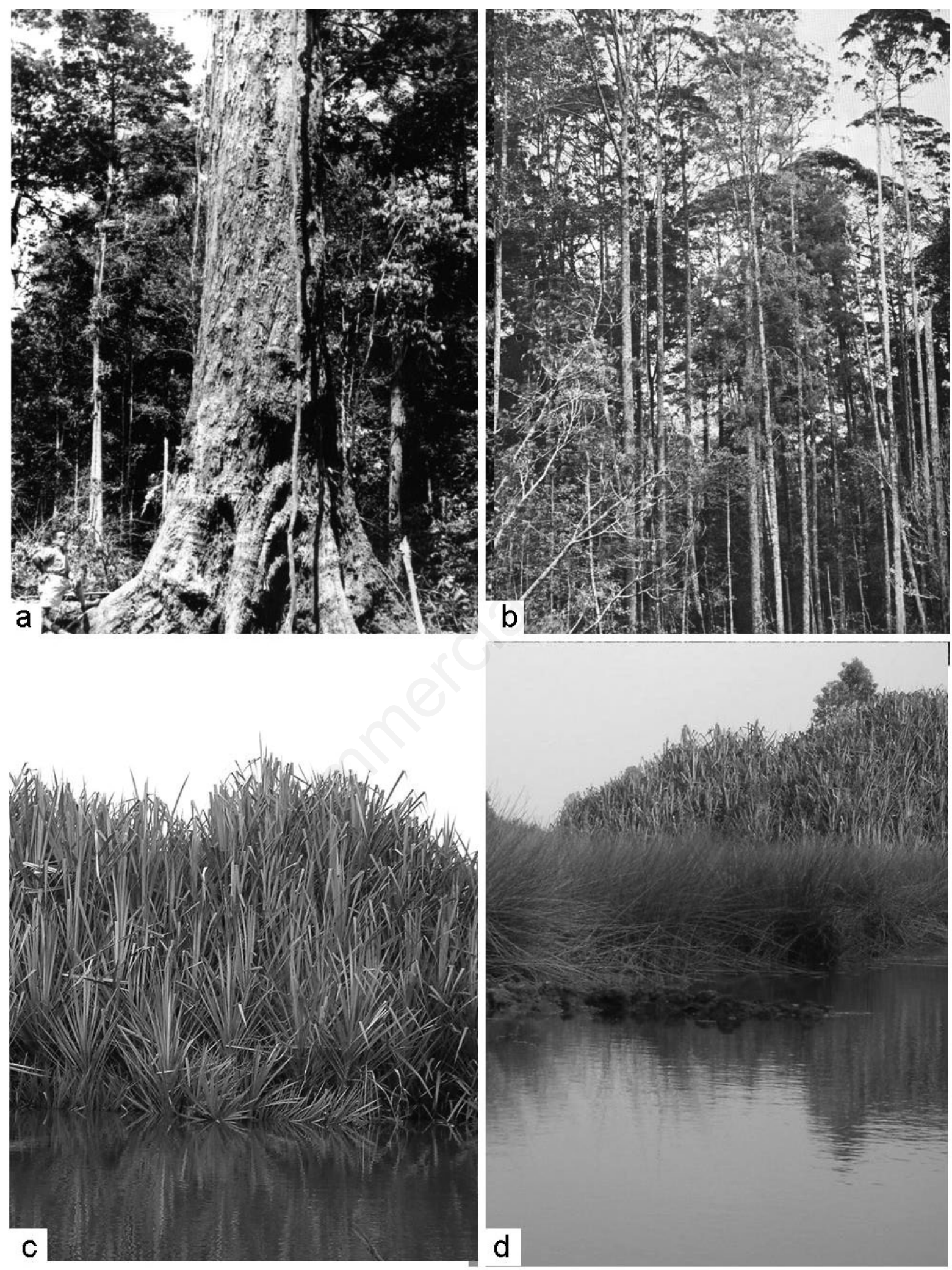

Fig. 4. a) Basinal peat swamp forest, large bole of Shorea albida (photo by P.S. Ashton); b) kerapah forest, Lawas, Brunei, with Gymnostoma nobilis (umberella shaped crown) and Dacrydium beccarii (feathery crown) dominant [from Whitmore (1975) (courtesy of J.A.R. Anderson)]; c,d) rheotrophic peat swamp, Tasek Bera, West Malaysia; c) Pandanus helicopus dominant; d) Tasek Bera, Lepironia articulata in foreground. 
sibly three phasic communities are present: mesophyllous mixed swamp forest (ph. 1) around the margins of mires; notophyllous pole forest (ph. 5), which is often termed Padang, in central areas; and open microphyllous/notophyllous woodland comparable to ph. 6 may occur in very mature swamps.

Mixed swamp forest from Riau province were dominated by Durio carinatus, with Palaquium spp., Dyera lowii (Apocynaceae), Gonystylus bancanus, Strombosia javanica (Olacaceae) and Shorea spp. present in the upper canopy (Anderson, 1976), whereas from Sebangau in South Kalimantan, Calophyllum spp. (Guttiferae) were overwhelmingly dominant with widespread Gonystylus bancanus. Padang forest from Riau was dominated by Palaquium spp. Parastemon urophyllum and Alstonia pneumatophora, whereas from South Kalimantan (Sebangau), Palaquium spp., Calophyllum retusum and Diopyros evena (Ebenaceae) were dominant elements (Anderson, 1976).
The more advanced phasic communities of basinal peat swamps are clearly related, both floristically and physiognomically, to kerangas forests, which are stunted, notophyllous, open-canopied forests of white podsolic sands which occur widely in Sarawak (Brunig, 1974), Central Kalimantan and elsewhere (Whitmore, 1984). Brunig (1990) considers all the phasic communities of basinal peat swamp forests to be closely related to kerangas forests, for there are more species in common with kerangas forests than mixed dipterocarp forests. Within ph. 1 and $2,75-85 \%$ of peat swamp species also occur in kerangas, whereas within ph. 5 and 6 , this increases to 100\% (Brunig, 1990), and Anderson (1983) notes that there are no species confined to basinal peat swamp forests. Brunig (1990) suggests that kerangas/kerapah has been, and still is, a stepping stone for dryland forest species to adapt for invasion and occupation of basinal peat swamps.

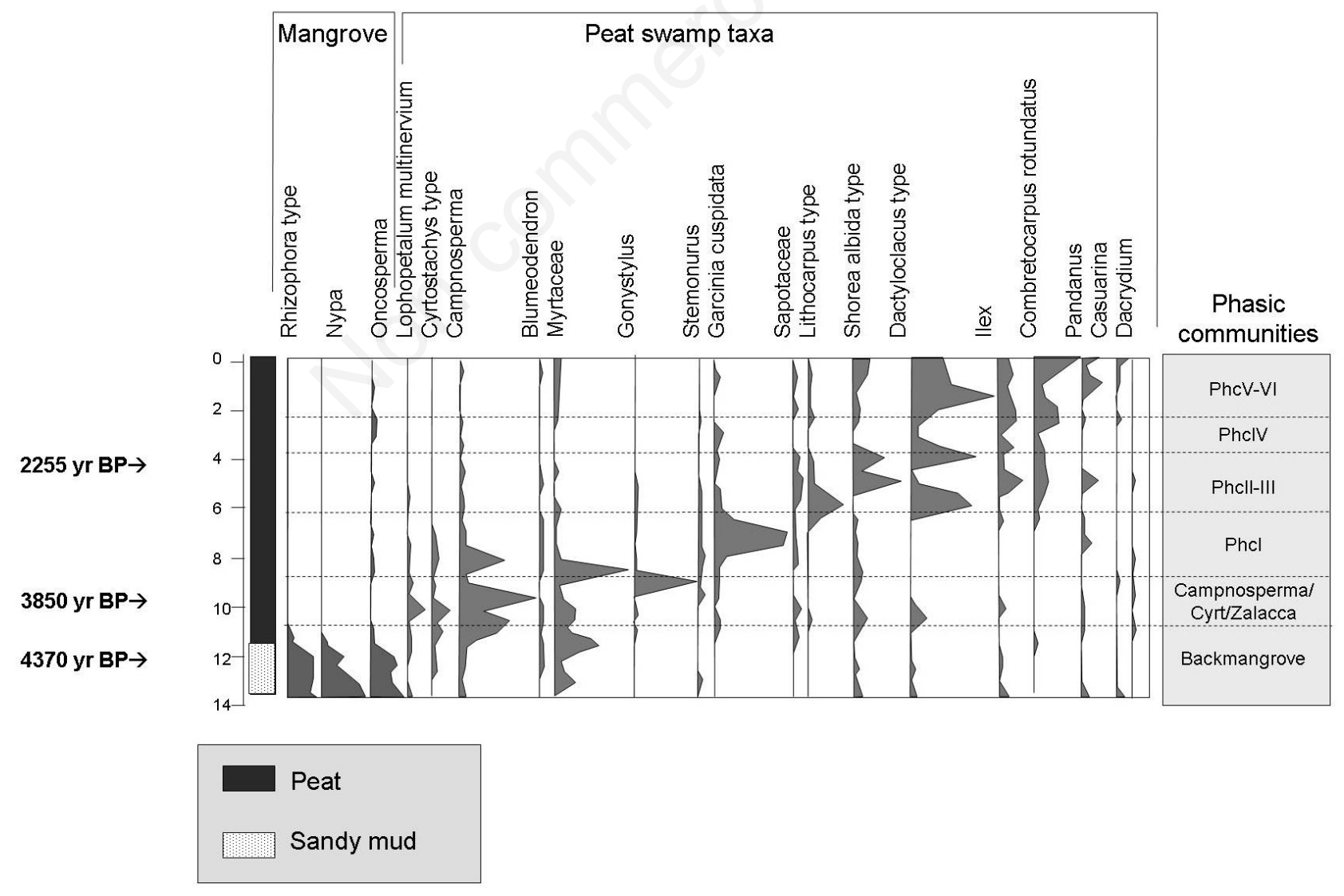

Fig. 5. Summary of pollen diagram from Marudi, Sarawak [summarised from Anderson and Muller (1975)]. Selected taxa are shown only. $\mathrm{Phc}=$ phasic community. Pollen sum total arboreal pollen. 


\section{Kerapah peats}

Kerapah forests, first studied in detail in Sarawak by Brunig $(1974,1990)$ occur there on thin peats, up to just $2 \mathrm{~m}$ thick (Fig. 2B). However, kerapah peats may attain substantial thicknesses of up to $12 \mathrm{~m}$ in inland localities in South Kalimantan (Fig. 1b) (Seiffermann et al., 1992), and possibly up to $16 \mathrm{~m}$ in the Kutei lakes area in East Kalimantan (Hope et al., 2005). Kerapah peats develop in areas of podsolic soils where drainage is impeded through the development of an iron or humic pan (Brunig, 1974, 1990), and the term watershed peats applies to such swamps occurring on low lying interfluves. Thus, they are particularly widespread as drapes on low-lying, lowland watersheds in areas of podsolic soils (Sieffermann et al., 1992), but also occur adjacent to freshwater lakes (e.g. lake Sentarum, West Kalimantan (Anshari et al., 2001), in Kutei, and on low plateaus within the upper limits of the lowland rain forest formation, in areas of impeded drainage, such as on Gunung Panti in southern Malay peninsula, and the Merurong plateau in Sarawak (Brunig, 1974; Corner, 1978). Montane peat-forming forests drape watershed areas at very high altitudes within the upper montane rain forest formation (Whitmore and Burnham, 1969; Flenley et al., 1972). Since upland peats are rarely preserved in the geological record, this account deals only with lowland peat-forming vegetation, occurring below $1000 \mathrm{~m}$ asl.

Kerapah peats develop over quite different timescales to basinal peats, their formation depending primarily on climate and secondarily on drainage factors, and unlike basinal peats need not to be directly connected to the cycle of sea level change. The oldest peats are from inland sites, such as lake Sentarum in the Kapuas lakes area and Sebangau in Kalimantan (see below) dating from 28 and 35 thousand years (ka) ago, respectively. They have been studied most intensively in the Sebangau region of Kalimantan (Fig. 6) by Morley (1981a), Sieffermann et al. (1992), Page et al. (1999, 2006), Rieley and Page (1997)

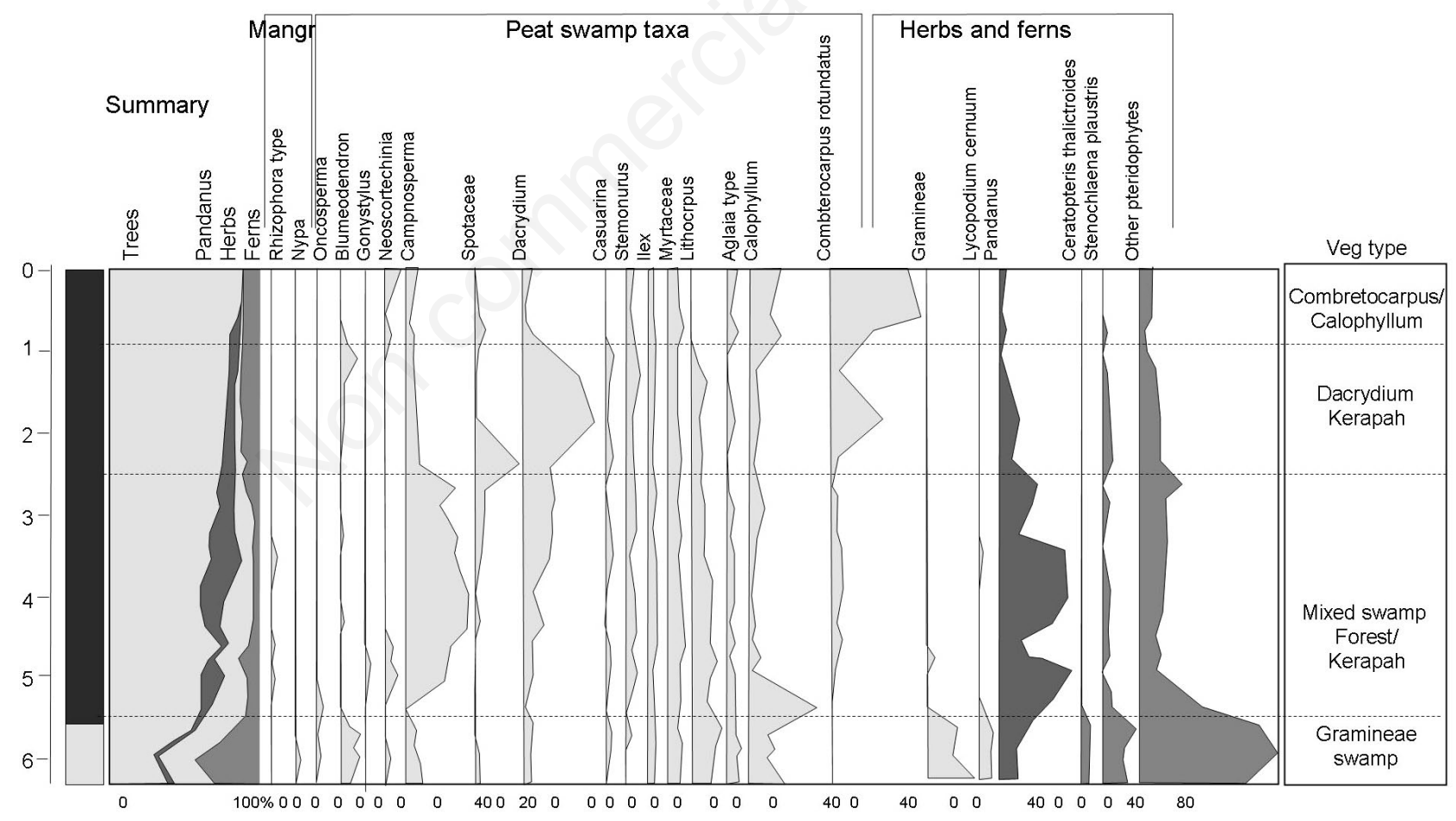

Detritus mud

Silt

Fig. 6. Summary of palynological analysis through peat at Sungei Sebangau, Kalimantan Tengah [summarised from Morley (1981a)]. Selected taxa are shown only. Pollen sum total arboreal pollen except for herbs + pteridophytes which are presented in terms of total pollen and total pollen and spores, respectively. 
and Kershaw et al. (2000), although an integrated overview is still wanting. The peat swamp succession in Sebangau is complex and requires detailed explanation, since basinal and kerapah peats occur in association. The peats from this area formed as drapes on an old watershed about $20 \mathrm{~m}$ asl and the oldest are dated from 35-20 ka, prior to the last glacial maximum (LGM). The peat is characterised by abundant fern spores and Cyperaceae pollen (Wurst et al., 2007) and most likely formed within a rheotrophic herbaceous marsh, the Gramineae swamp of Morley (1981a, 1981b). No peat formation took place during the LGM, because during this time it is thought that the climate was too dry for peats to form (Page et al., 1999; Morley, 2012). Peat formation recommenced after the LGM, initially within a herbaceous marsh setting, but subsequently, after about $10 \mathrm{ka}$, and possibly as early as $13 \mathrm{ka}$, within an ombrotrophic setting with the development of peat swamp forests. Ombrotrophic peat formation thus began when the sea level was from 40 to $90 \mathrm{~m}$ below the levels of the mid Holocene. It is suggested that peat initiation commenced after a change to a wetter climate, probably associated with the sudden sea level rise after about $13 \mathrm{ka}$ (Morley, 2012). Peat formation within a kerapah setting continued in this area until about $6 \mathrm{ka}$ (Page et al., 1999), after which time peat formation ceased, possibly due to a change to a more seasonal climate. The peat at this location is much drier than actively growing peats from the same area (Sieffermann et al., 1992; Page et al., 1999), no doubt due to a long period without growth, and possibly also with deflation. Sometime after $2000 \mathrm{bp}$, peat formation recommenced in the same area, following the growth of basinal peats along the Sebangau river (Fig. $1 b$ ), and most likely has been continuing up to the present day. The vegetation growing on the basinal peat exhibits some degree of concentric zoning as noted above (Anderson, 1976; Page et al., 1999).

It is suggested that peat swamps in the Kutei lakes area, studied by Hope et al. (2005) are also of the kerapah type; these started to form as sea levels continued to rise during the early Holocene, but before the development of widespread basinal peats along coastlines. They probably started to form as the Mahakam delta began to build out from its present position during the latter period of sea level rise, following infill of the Mahakam incised valley, resulting in the development of paludal conditions in the Kutei lakes area.

Kerapah forest composition has been studied in detail only in Sarawak and Brunei by Brunig (1968, 1974, 1990), and is floristically similar to kerangas. Although Brunig (1990) noted structural trends and concentric zoning within kerapah peat swamps which bear some similarities with those seen in basinal swamps (Fig. 2), he was not able to identify consistent trends between forests on different mires, in the manner of the coastal/delta peat swamps studied by Anderson. He attributed this to the much greater inter- and intra-stand floristic variation within kerapah compared to basinal peat swamp forests, and this reflects the much higher floristic diversity of kerangas vegetation (948 species recorded in Sarawak kerangas/kerapah forests, as opposed to 242 species in basinal peat swamps). Greater diversity of kerapah peats may be a reflection of their greater geological age (see below). Two important kerapah genera which are generally absent from basinal peat swamps, and which deserve special mention are Dacrydium (Podocarpaceae) and Gymnostoma (Casuarinaceae), since they often occur together and achieve single species dominance (Brunig, 1990). Gymnostoma and/or Dacrydium seem to have been important elements of most of the kerapah swamps studied, and their presence seems to be a good indicator of kerapah swamps. Brunig (1990) also suggests that their tannin-rich leaves prevent litter decomposition, and increase peat-forming tendencies. Other kerapah elements are Falcifoliatum and Podocarpus (Podocarpaceae), and Tristania (Brunig, 1990).

The canopy of kerapah forests at Sebangau, summarised by Page et al. (1999), included Agathis dammara (Araucariaceae), Calophyllum spp., Dactylocladus stenostachys, Dipterocarpus coriaceus, Gonystylus bancanus, Gymnostoma sumatrana, Palaquium spp., Vatica mangachopei (Dipterocarpaceae), Xylopia spp. (Anonaceae), Leguminosae and Myrtaceae. However, this forest is growing on old peat, and may thus not reflect a true successional stage. A very low canopied forest from waterlogged areas in the same locality was characterised by Calophyllum spp., Combretocapus rotundatus, Cratoxylum spp. (Guttiferae), Dactylocladus stenostachys, Litsea spp. (Lauraceae), Plioarium alternifolium (Theaceae) and Tristania spp. (Page et al., 1999).

Palynological studies of both lowland and upland kerapah peats from Sarawak have been performed by Muller (1963), with pollen diagrams presented here in Fig. 7, and published by Brunig (1974). Although the diagrams show some minor temporal trends, these are difficult to interpret. The most distinctive feature of the diagrams is their characterisation by common to abundant Dacrydium and Casuarina type pollen, which, as noted above, are thought to provide evidence for differentiating kerapah from basinal swamps.

Muller (1963) also made some brief comments on palynological analyses on a peat profile from an anomalous lowland peat swamp at Lawas, in Brunei (Anderson, 1963), which is dominated by Gymnostoma nobilis and Dacrydium elatum (Fig. 4b). Brunig (1990) proposed that this swamp should be classified as kerapah, rather than a basinal peat swamp, despite its coastal locality. The detailed palynological analysis of Lawas (Fig. 8) (Muller, unpublished data; Morley et al., 2011) clearly shows that 
Dacrydium colonised directly over mangrove muds, a kerapah swamp forming presumably because of the proximity of kerangas vegetation on adjacent podsolic soils. The continued dominance of Dacrydium, and later Gymnostoma (from the presence of Casuarina type pollen), throughout the peat profile, supports the suggestion of Brunig (1990) that Dacrydium and Gymnostoma leaf litter may have an allelopathic capacity, retarding the regeneration of other taxa.

Palynological profiles through the Sebangau peat swamp adjacent to the Sebangau river, show an initial development of mixed swamp forest (ph. 1) with common Pandanus and Campnosperma, over alluvial swamp (Morley, 1981a), probably dating from $\sim 10 \mathrm{ka}$. Yet, they also show that subsequently the vegetation became dominated by Dacrydium (Fig. 6), thus suggesting a kerapah swamp, which probably continued to build up until about $6 \mathrm{ka}$. The youngest peats however, forming after $\sim 2000$ bp are dominated by Calophyllum and Combretocarpus and these are thought to reflect the Padang stage of basinal peat swamp. The succession until the end of the kerapah phase is very similar to that recorded from the Kutei lakes by Hope et al. (2005), with an initial succession with common Pandanus, followed by a vegetation with common Campnosperma, and subsequently with common to abundant Casuarina type (probably from Gymnostoma) and Dacrydium. The Kapuas lakes succession, analysed by Anshari et al. (2001), showed a similar succession, with an initial stage dominated by Anacardiaceae and Sapotaceae, followed by a later stage with Calophyllum and Gymnostoma.

Because kerapah peats are less common than basinal peats, and because there is clear evidence for their decay, it is very likely that kerapah peat swamp vegetation was formerly more extensive. It is noteworthy that no peats older than $30 \mathrm{ka}$ have been reported from inland localities in Borneo, suggesting that older peats in interfluve areas were mostly destroyed by oxidation during periods of drier climate such as during the LGM, older peats being preserved mainly in coastal locations where there was subsidence. It was also suggested that kerapah swamps may have been widespread across the Sunda shelf in areas which were exposed when sea levels were $50 \mathrm{~m}$ below present levels (Slik et al., 2011).

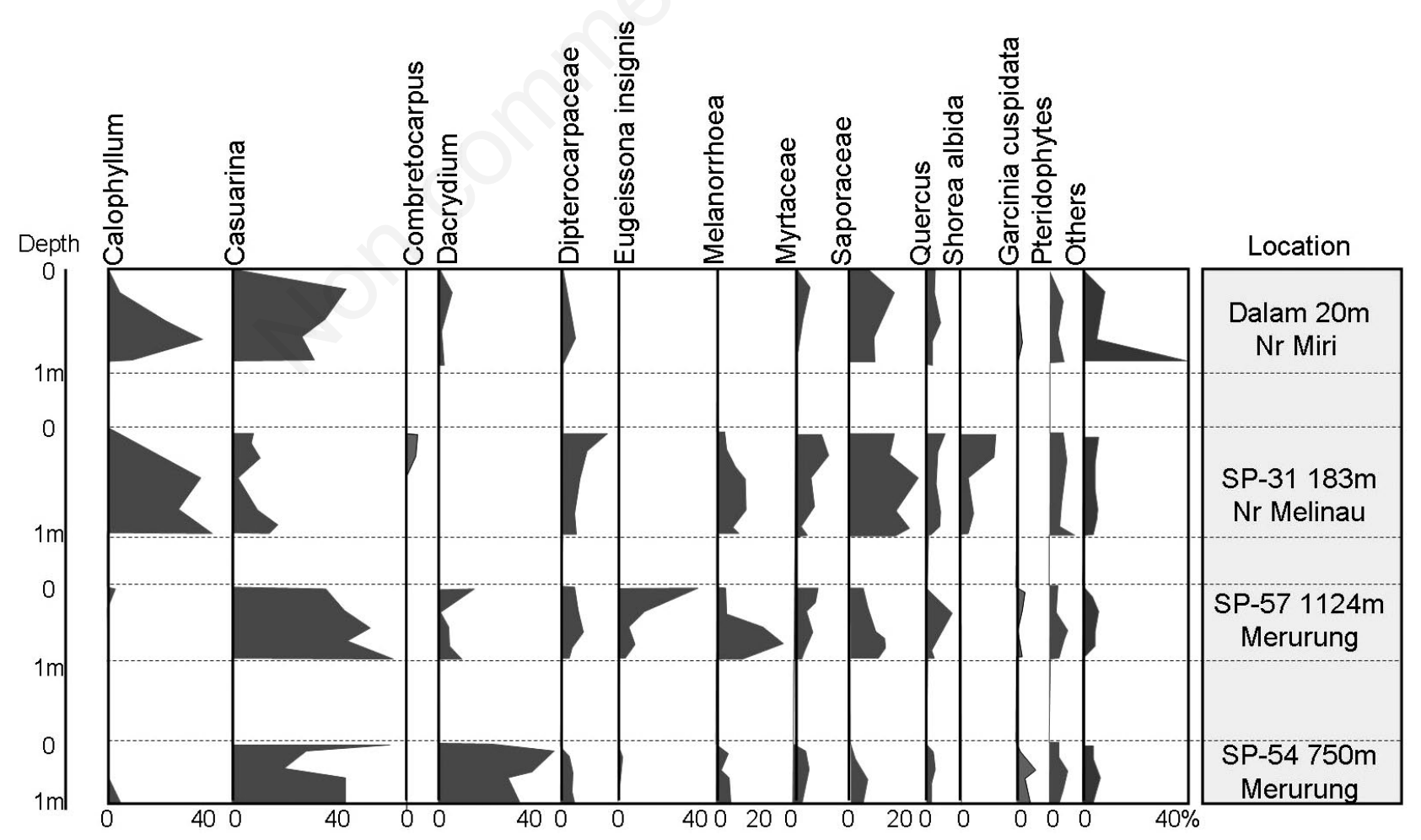

Fig. 7. Palynological successions through four modern kerapah peats (Brunig, 1974). Rare taxa excluded, pollen sum total arboreal pollen. Dalam, $20 \mathrm{~m}$ asl, coastal locality near Miri, Sarawak; SP-31, inland locality at $183 \mathrm{~m}$ asl, near Melinau, Brunei; SP-54 and SP57, inland locality on Merurong plateau, at 1124 and $730 \mathrm{~m}$ asl, respectively. 


\section{Rheotrophic swamps}

Rheotrophic swamps occur widely throughout Southeast Asia, although few have been studied in detail. They vary from large swamps within tectonically controlled depressions (e.g. Air Batang Toro swamp in the Semangko rift valley of Sumatra and Tasek Bera in West Malaysia) to infilled volcanic craters (e.g. Rawa Danau in West Java), infilled oxbow lakes, and many others. The extensive Berbak swamp in Jambi province, South Sumatra is also likely to be mainly rheotrophic, as it shows a planar, rather than domed succession (Esterle and Ferm, 1994). It is thought that this swamp differs from others due to rapid subsidence in this area, as the oldest peats, dated to just $4250 \mathrm{bp}$, are now over $5 \mathrm{~m}$ below present sea level. Although many rheotrophic swamp settings may rapidly infill with sediment, they may not necessarily all be peatforming; this discussion will be confined to those swamp vegetation types which are known to develop peats, or detritus muds, and other vegetation types which, it is believed from the fossil record, may have been important in

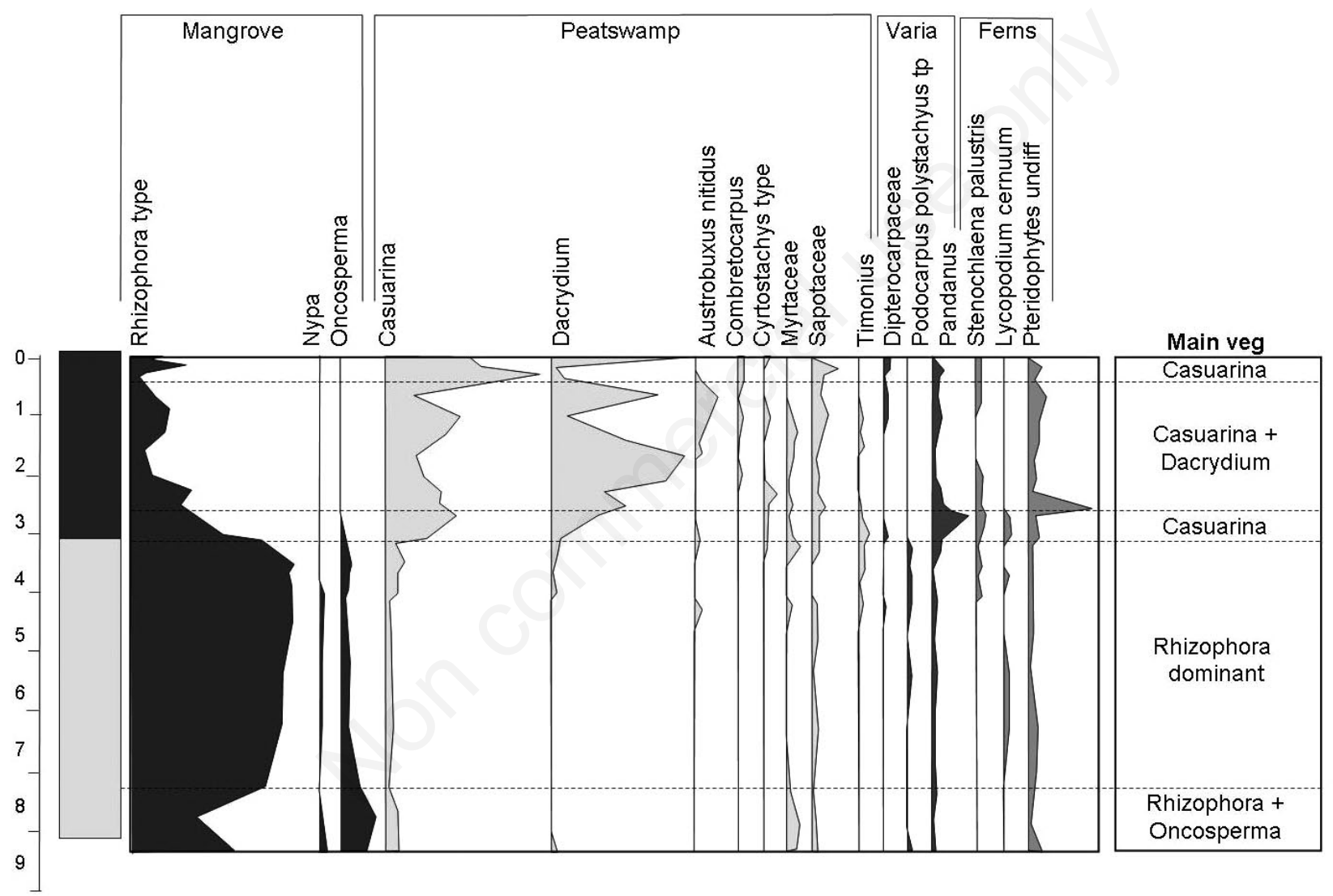

Peat

Silt

Fig. 8. Palynological analysis through peat and underlying muds at Lawas, Brunei (Muller, unpublished data). Selected taxa are shown only. Pollen sum total arboreal pollen except for fern spores which are presented in terms of total pollen and spores. Dominant palynological components are indicated on the right. 
forming peats during the Tertiary. Alluvial or freshwater swamps are excluded from consideration, since these associations are not peat-forming.

\section{Palm-dominated swamps}

The vegetation of the extensive Berbak swamp forest in South Sumatra (Fig. 1d), briefly described by Dransfield (1974), is dominated by rattans (Palmae), including Calamus, Daemonorops and Korthalsia, together with other palms, such as Pinanga, Licuala and Pholidocarpus. This is the only known large swamp characterised by common palms. This swamp lies in a coastal setting, behind a wide swathe of Pandanus helicopus (Pandanaceae), with Oncosperma and Nypa occurring (both Palmae) extensively in brackish, coastal regions. The dominance of palms in coastal swamps may therefore be indicative of rheotrophic swamps. Esterle and Ferm (1994) also note extensive areas with mixed swamp forest indicating minor doming, and thus it is possible that in places this swamp is developing into a basinal type ombrotrophic swamp.

Rattans are also mentioned as being important com- ponents of vegetation in swamps on the Citarum delta, Java (Van Steenis and Schippers-Lamertse, 1965), in the Rawa Lakbok, in Central Java (Polak, 1950), and in the Opa swamp in South East (SE) Sulawesi (Jacobs et al., unpublished report, and rattan brakes are recorded in poorly drained areas in Myanmar (Dudley-Stamp, 1925). It is noteworthy that a number of these sites occur in areas with a distinct seasonal climate. Since there are no palynological studies in any of these localities, it is not possible to comment on their contribution to swamp vegetation through time.

\section{Pandanus swamps}

Pandanus spp. form extensive swamps within blackwater lakes in the Malay peninsula, such as Tasek Bera, and Tasek Chini in Pahang. Tasek Bera is a drowned river valley which began to infill with detritus muds some time after 4500 years ago, (Morley, 1981b, 1982b; Wüst and Bustin, 2004). The lake is acid, although less so than basinal or watershed peats, and has a $\mathrm{pH}$ of about 5.5 (Furtado and Mori, 1982). The major part of the area is vegetated

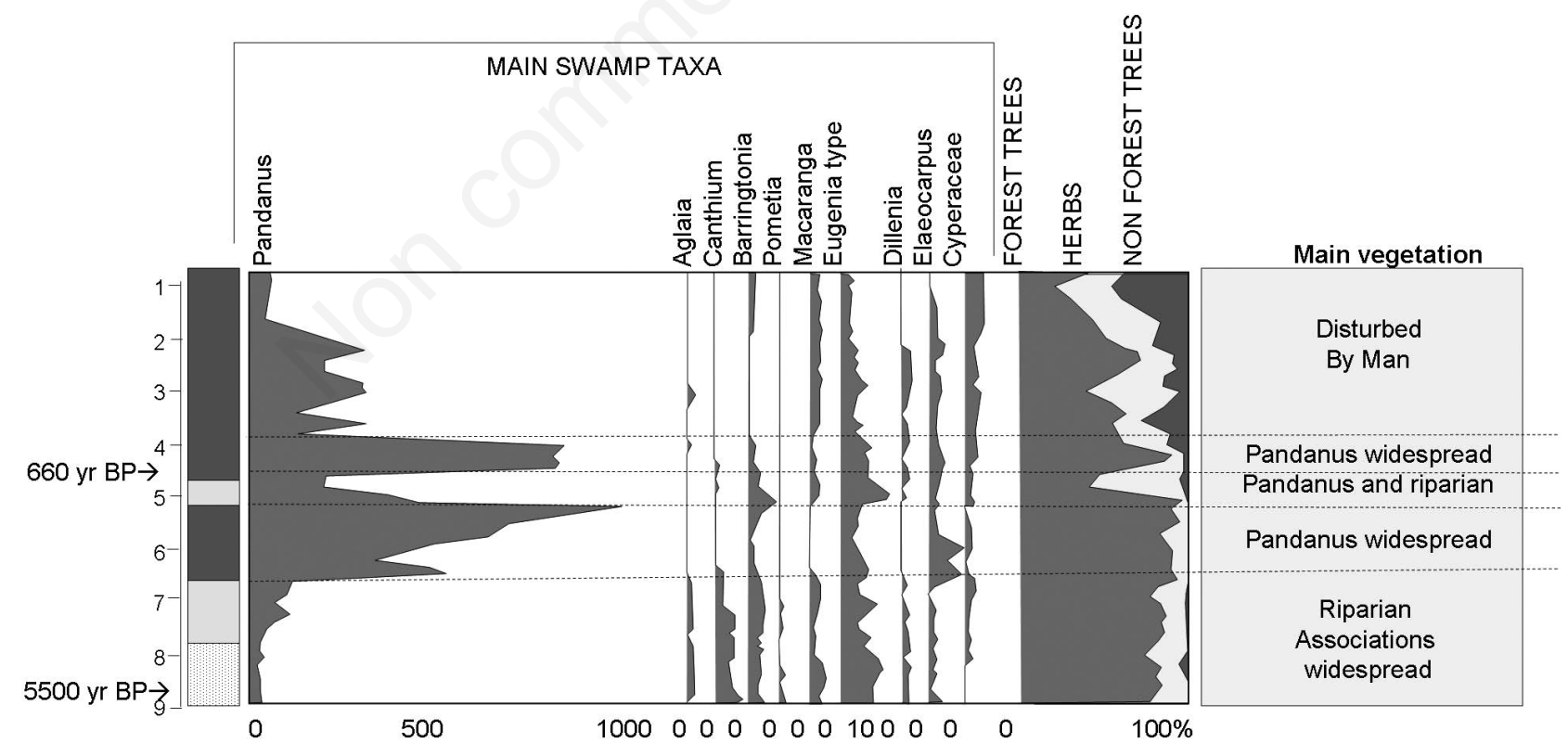

Detritus mud

Silt

[17:?] sand

Fig. 9. Summary of palynological analysis at Tasek Bera, Pahang, Malaysia [summarised from Morley (1982a)]. Selected taxa are shown only. Pollen sum total pollen excluding Pandanus, which is calculated outside the sum; note different scale for Pandanus. Aglaia, Barringtonia, Canthium, Pometia and Macaranga are probably components of riparian vegetation. 
by a consocies of Pandanus helicopus (Fig. 4c), and Lepironia articulata (Cyperaceae) marsh is also extensive (Fig. 4d). Pandanus spp. were widespread in this location since the initial formation of detrital sediments (Fig. 9), and were in fact much more extensive prior to burning of the vegetation by forest-dwelling peoples during the last 600 years. Before the development of Pandanus swamps, the river valley bore a typical streamside vegetation with Canthium (Rubiaceae), Barringtonia (Lecythidaceae), Macaranga (Euphorbiaceae), and Pometia (Sapindaceae). Intermittently, Elaeocarpus (Elaeocarpaceae) formed a significant swamp element (Morley, 1981b).

Pandanus helicopus swamps occur extensively along a number of river courses on the East coast of the Malay peninsula, such as Sungei Sedili and South Kuantan, and in western Sarawak, and as noted above, seaward of the Berbak swamp in South Sumatra. They also possibly occur in Benkalis (Sewanando, 1938). The widespread Pandanus swamps are restricted to coastal areas which are affected by tides, but too far inland to receive brackish influence (Corner, 1978; Morley, 2000).

\section{Swamp forests}

Forests growing on rheotrophic peat swamps are widespread, but have been very poorly studied. In West Java, the swamp forest at Rawa Danau includes species of Elaeocarpus littoralis, Alstonia (Apocynaceae), Ficus (Moraceae), Lagerstroemia (Lythraceae), Eugenia, Ilex (Aquifoliaceae) and Barringtonia among its dominants (Endert, 1932). This locality has been studied palynologically by van der Kaars et al. (2001) and shows a succession from open grass-dominated swamp prior to $13 \mathrm{ka}$, to a swamp forest with Elaeocarpus, Moraceae, Dipterocarpaceae and Euphorbiaceae for most of the Holocene, but with Elaeocarpus becoming dominant during the latest Holocene. Stands of Elaeocarpus littoralis have also been noted in freshwater swamps near Jakarta by van Steenis (1934).

An interesting patchwork of swamp forest communities occurs at Danau Padang, a small peat-filled lake basin at $950 \mathrm{~m}$ asl in Sumatra (Morley, 1982a). The swamp vegetation at this site can be divided into Ilex swamp, dominated by Ilex cymosa, which occurs in peripheral areas, and Myrsine swamp which is characterised by Myrsine affinis and M. avenis (Mysinaceae) and occurs close to a central open water area which is surrounded by marsh dominated by Machaerina rubiginosa (Cyperaceae). Palynological studies reveal a succession of swamp vegetation at this site. Initially, a swamp forest with Ilex and Myrtaceae, surrounding an extensive open water area, gave way to a swamp forest dominated by Elaeocarpus sp. This in turn was replaced by Myrsine spp. and herbaceous swamp. It is likely that the Myrsine swamp reflects a trend toward greater oligotrophy, since there is a close association with the pitcher plant Nepenthes.

\section{Brackish peats}

Only one example of autochthonous peat-forming settings is known within brackish environments from SE Asia at present day; dense stands of Sonneratia caseolaris (Sonneratiaceae) were noted growing on rather acid, peaty soil on the eastern coat of North Sumatra (Bunning, 1947). Thin peats are associated with beach ridges on the Mahakam delta (Allen et al., 1979; Gastaldo et al., 1993), but these are allochthonous, and are formed mainly of coarse woody debris carried by water. However, a study of coastal sediments by Yulianto et al. (2004) from South West (SW) Sulawesi shows the presence of early Holocene peats which were in part dominated by Rhizophora pollen, with subordinate Avicennia and Sonneratia. Also, a study of the Thale Noi peat swamp, near the Sonkla lakes in South Thailand (Horton et al., 2005) indicates that true mangrove peats developed for a very short period immediately following the early Holocene sea level rise, about 6900 years ago, but were replaced after a short time by mixed swamp forest. Clayey peats dated to isotope stage 4 from near Penang, West Malaysia (Kamaludin and Yakzan, 1997) were dominated by mangrove pollen, suggesting formation within a widespread mangrove swamp, perhaps when this area was an isolated island. Mangroves have thus formed peats during the late Quaternary, although none appear to be forming today.

Mangroves growing on peats are, however, widely reported on oceanic islands in areas of everwet climate, forming above carbonates, in the western Pacific (Ellison, 2009). Similar settings occur in the Caribbean (Spackman et al., 1966).

\section{OVERVIEW OF CENOZOIC HISTORY OF PEAT-FORMING VEGETATION IN SOUTHEAST ASIA}

Palynomorph names: Cenozoic pollen types are referred to pollen of extant taxa in cases where determinations are unequivocal, and to form taxa in instances where determinations are questionable, or parent taxa are clearly extinct. The suffix type is used if a pollen type is identical to pollen of two or more extant taxa.

\section{Paleocene}

The oldest coals examined palynologically from the Southeast Asian region are of Paleocene age, and are noted within the Tabyin-Laungshe formation in Myanmar, and the Pre-Nimbang formation from the East Java sea (Reimann and Thuang, 1981; Morley, 2000). Palynomorph assemblages from these coals are dominated by an undescribed trichotomosulcate pollen type which is believed to be from an extinct palm and shows closest morphological similarity to pollen of the central American genus Gastrococcus (Tricolpites types A-C; Reimann and 
Thuang, 1981), and due to the dominance of this pollen type, vegetation growing on peats at this time was probably of very low diversity indeed; none of the remaining pollen types recorded within these coals can be referred to extant plant families (Morley, 2000).

\section{Middle and Late Eocene}

Middle Eocene coals from the Nanggulan, Bayar and Ngimbang formations of Java, the Mallawa formation of Southwest Sulawesi and the Tanjung formation of Southeast Kalimantan have been studied palynologically to some degree, although most of this work remains unpublished. The ecological development of Middle Eocene coals is best illustrated by reference to studies of a $50 \mathrm{~cm}$ thick coal from the Nanggulan formation in Central Java (Barton, unpublished thesis; Morley, 2000) which has been examined in some detail, with results summarised in Fig. 10. As with the Paleocene, assemblages are dominated by palm pollen, but of markedly different composition. The trichotomosulcate form which dominated older coals is absent, and is replaced by Palmaepollenites spp. (Palmae), especially P. kutchensis, which is thought to have been produced by extinct members of the tribe Iguanurinae (Harley and Morley, 1995). This group of palms, together with many other taxa, is believed to have dispersed to Southeast Asia from India, following the colli- sion of the Indian and Asian plates in the Middle Eocene (Morley, 1998, 2000) and their appearance is thought to relate directly to the extinction of earlier groups. Other characteristic palm pollen types within this coal are Calamus type, produced by rattans, and Nypa, together with the form-genus Proxapertites spp., thought by Muller (1968) and Morley (2000) to be derived from an extinct group of nypoid palms, but by Zetter et al. (2001) more likely from an extinct aroid. Whatever its identity, the succession of Proxapertites pollen relative to that of Nypa and foraminiferal tests in paralic sediments from many localities suggest an origin from a mangrove plant.

Pollen spectra through this coal show a clear ecological succession. The lower part, and the topmost sample contain regular Nypa pollen and Acrostichum (Pteridaceae) spores, suggesting brackish influence; the curves for Nypa, Acrostichum, Florschuetzia trilobata (Lythraceae/Sonneratiaceae) and cf. Lagerstroemia (Lythraceae/Sonneratiaceae) and Brownlowia type (Tiliaceae) follow the same trend with two maxima, and it is likely that the parent plants of the latter taxa also grew under brackish conditions. Iguanuroid palm pollen dominates the upper part, which clearly accumulated under wholly freshwater conditions. Bearing in mind the return of pollen of brackish taxa in the topmost sample, it is likely that peat accumulation was terminated by marine transgression.

Samples examined from other Nanggulan coals are

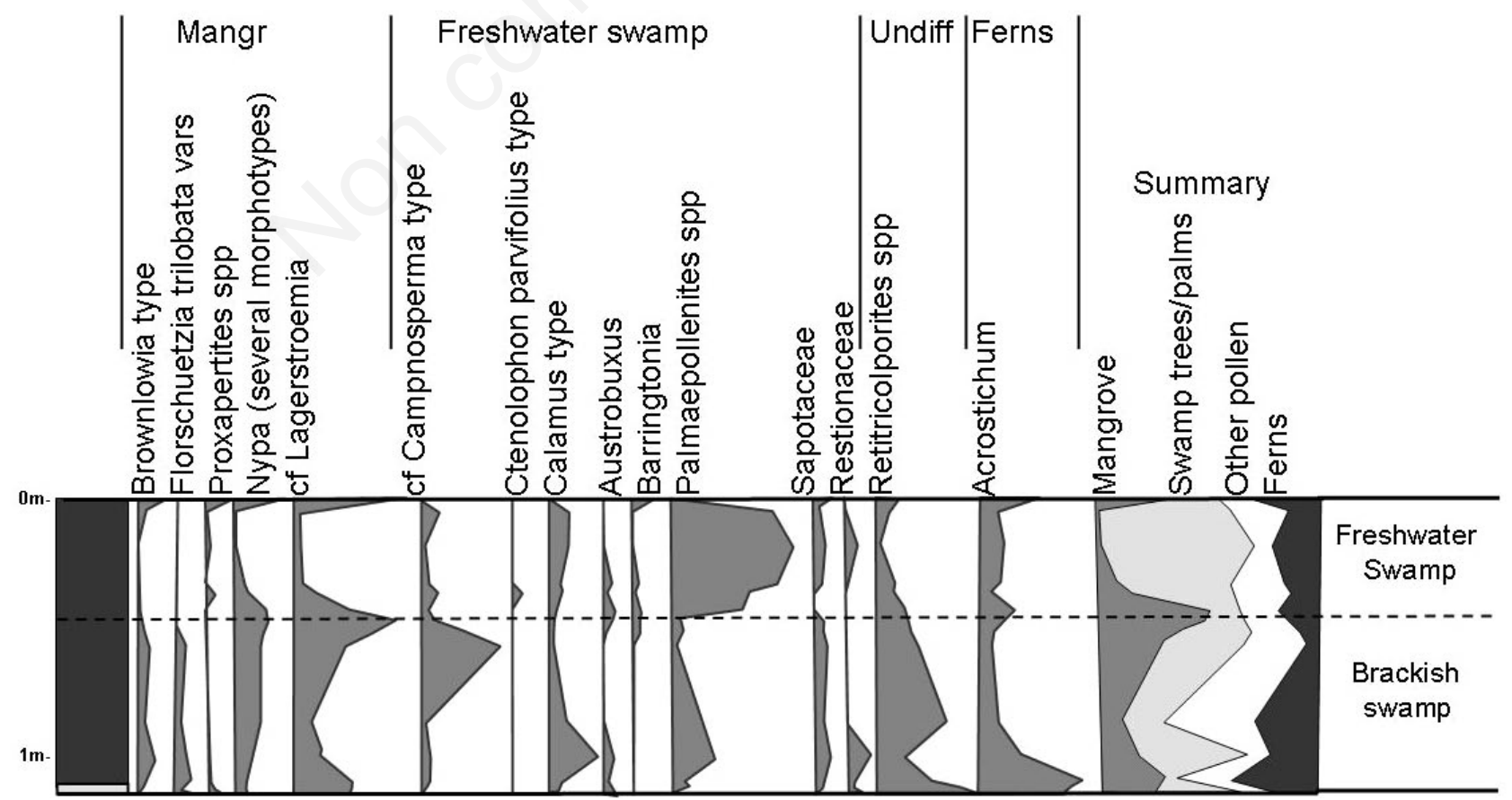

Fig. 10. Palynological analysis of Middle Eocene coal from Nanggulan, Central Java, selected taxa are shown only [from Morley (2000)]. Pollen sum total miospores; lithologies are to the left of the diagram. 
also rich in pollen of dicotyledonous trees, including a species of Polygalaceae, Ixonanthes (Ixonanthaceae), Ctenolophon parvifolius (Ctenolophonaceae) and a Sapindaceous tree that produced the pollen type Cupanieidites flaccidiformis (closely comarable to some forms of Mischocarpus). In general, the diversity of palynomorphs within coals from this formation is considerably less than the diversity of assemblages from adjacent mudstones, suggesting that in the same manner as today, Eocene peatforming vegetation was less diverse than surrounding dryland forests. The succession from brackish to freshwater, without evidence for subsequent succession within the freshwater interval that might relate to nutrient availability, is thought to suggest that peat formation occurred in a rheotrophic, rather than ombrotrophic setting.

The palynomorph associations within the above coal are probably typical of most Middle Eocene coals from the southeast margin of Sundaland. For example, thin coals from the Bayar formation in West Java are dominated by pollen of brackish nypoid palms (or extinct aroids), whereas some coal samples from the Mallawa formation in Southwest Sulawesi proved to be dominated by pollen of iguanuroid palms.

Coals of Late Eocene age have been examined from the Tanjung formation in southeast Kalimantan (Dettmann and Playford, unpublished report; Witts et al., 2012), from the latest Eocene of the Mangkalihat peninsula (Morley, 2000), and from the Yaw formation of Myanmar (Potonie, 1960). The Tanjung coal studied by Dettmann and Playford (unpublished report) was $7 \mathrm{~m}$ thick, with the seam base accumulating in a wholly freshwater setting, but with brackish influence being present in the upper part, and with peat accumulation presumably ceasing due to marine transgression. The Mangkalihat coals, which are from a number of poorly exposed outcrops of uncertain stratigraphic relationship, are dominated by pteridophyte spores, suggesting a much more open, herbaceous vegetation, with subordinate iguanuroid palms and rattans. Nypa pollen and Proxapertites occur in low frequencies, suggesting some brackish influence. In addition, these coals contain common Meyeripollis naharkotensis (possibly Myrtaceae), which, from its fossil distribution, occurring commonly in association with coaly lithologies, but virtually absence from areas of seasonal palaeoclimate, is believed to have been produced by a swamp-forest tree. Rattan pollen (Calamus type) was dominant in the coal sample analysed by Potonie (1960) from the Yaw formation of Myanmar, suggesting an open vegetation with palm thickets. Each of these coals is likely to have formed in a rheotrophic setting.

\section{Oligocene}

There was a major change to monsoonal, or seasonal climates at the end of the Eocene, which affected a major part of the region of Southeast Asia (Morley, 1998, 2000, 2012). Coal-forming environments through most of the Oligocene, until the Late Oligocene thermal maximum, were of very restricted occurrence. Extensive Oligocene coals are known only from the Sawahlunto formation (Ombilin basin), where they form part of the initial rift infill sequence (Koesoemadinata and Matasak, 1981) and from the Pematang formation of Jambi province. The Sawahlunto coal grades laterally into lake deposits (Wateley and Jordan, 1989), and is also rich in algal remains, such as Pediastrum spp. Therefore, the Sawahlunto coal most likely formed from a rheotropic, eutrophic peat. The limited data obtained from this coal suggests that Iguanurinae and ferns were important members of peat-forming vegetation (Bartram and Nugrahaningsih, 1990), but details of the vegetational succession remain poorly known.

Thin coals are recorded from the early Oligocene Pematang formation in Central Sumatra, and palynological analyses demonstrate that these are characterised by abundant fern spores, in particular, the Schizaeaceous Cicatricosisporites dorogensis, and spores of the rooted or floating fern Ceratopteris (Parkeriaceae), which occur together with pollen of Oncosperma, Barringtonia and $\mathrm{Al}$ chornea (Euphorbiaceae) (Pribatini, unpublished thesis). These thin coals are believed to be the remains of localised rheotrophic peats or lake muds which formed in shallow depressions, perhaps in oxbow lakes at a time when the climate was distinctly seasonal. Similar very thin coals have been noted from well logs through the earliest Miocene of the Malay basin, and cuttings from these horizons also contain common spores of Ceratopteris. These also are believed to be rheophytic infill deposits, again possibly reflecting ephemeral oxbow lakes or ponds.

The Eocene palm-dominated swamp flora seems to have largely disappeared through the course of the Oligocene, possibly as a result of extinction following Oligocene climatic change, but equally may be due to habitat loss, since brackish peat mires would have been very poorly represented during the earliest Oligocene since everwet climates were of very restricted occurrence at that time.

Widespread peat formation recommenced at the time of the Late Oligocene thermal maximum, when extensive peats formed along the south coast of Sundaland, represented by coals within the upper part of the Talang Akar formation in South Sumatra, and lateral equivalents recorded in the subsurface of the Sunda and Arjuna basins in the West Java sea area, and also within the Coaly Cau formation of the Nam Con Son basin, south of Vietnam (Morley and Swiecicki, 2011) which formed along the eastern coast of Sundaland landmass (Morley, 2012).

The Talang Akar coals are mostly characterised by the 
presence of common to dominant Casuarina type pollen, and also Dacrydium pollen. The common occurrence of both Casuarina type (probably from Gymnostoma) and Dacrydium pollen suggests that these coals were probably derived from kerapah type peats, which must have been of very extensive occurrence from South Sumatra eastward at this time, and reflect two successive periods of very wet climate, probably as sea levels rose at the time of the Late Oligocene thermal maximum. These coals were thus of the ombrotrophic type. Kerapah peat swamp forest with Gymnostoma and Dacrydium is therefore a very ancient plant community. Studies from marine sediments in East Java (Lelono and Morley, 2011) indicate that these pollen types are associated back to the base of the Oligocene.

In addition to Dacrydium and Casuarina, Talang Akar coals are also rich in Calamus type pollen, suggesting that the swamp vegetation was rich in rattans, and locally, Pandanus pollen is common, perhaps reflecting rheotrophic swamps.

The Nam Con Son coaly Cau formation coals also formed within a coastal setting, but closer to the palaeocoastline in reach of brackish influence, and are thought to contain abundant (back) mangrove pollen of the form species Florschuetrzia trilobata (ancestral Sonneratia). This judgment is not certain, since these coals have been examined only in cuttings, rather than core.

\section{Miocene}

A major climatic change occurred through most of the region of Southeast Asia at the beginning of the Early Miocene (Morley, 2006, 2012) with the onset of the East Asian monsoon, at which time everwet climates became much more widespread. Peatlands must have been very extensive because, from the basal Early Miocene onward, coals are widely represented in the sedimentary records of many Southeast Asian basins, especially the West Natuna and Malay basins through the West Natuna Arang and Malay basin Sand/Coal formations.

\section{Kerapah peats}

Kerapah peats were important progenitors of coal throughout the Early Miocene of several Sunda shelf basins, including West Natuna, Penyu and Malay basin. In each of these basins, successive acmes of Casuarina type and Dacrydium pollen occured through the Early Miocene, associated with the early stages of successive depositional sequences, especially within Malay basin seismic group I and its lateral equivalents (Shamsudin and Morley, 2006), and then, following the mid Miocene thermal maximum, within seismic group E sequences (Morley, unpublished material). These acmes reflect periods of expansion of either kerangas vegetation or kerapah swamp, but in instances where coals are present and which have been sidewall cored, the coals typically yield common Casuarina type and Dacrydium pollen, suggesting kerapah swamp. In several instances from the Early Miocene of West Natuna, meandering channel deposits were sidewalled, anticipating channel sands, but the channels proved to be coal-filled, and the coals were dominated by Casuarina type pollen, again suggesting kerapah swamps infilling valleys, presumably at times of sea level rise when incised channels may have been abandoned.

Demchuck and Moore (1993) studied a thick Middle Miocene coal, the Sarongga lignite from Southeast Kalimantan (Fig. 11). This coal is over $20 \mathrm{~m}$ thick and Demchuck and Moore (1993) suggested that it formed from vegetation which was virtually identical to modern peatforming vegetation in Indonesia. They interpreted three palynological assemblages, but emphasised that due to the coarseness of the sampling interval, it was doubtful that these zones reflected a floral succession in the sense of modern peats, but that they reflected large-scale successional changes which were a product of long-term ecological shifts and changing depositional conditions within the original mire. The most distinctive feature of the Sarongga diagram is the regular occurrence of Casuarina and Dacrydium pollen, clearly suggesting an affinity to kerapah peat swamp forests rather than basinal peats, and also suggesting that the Sarongga peat formed as a drape, or as a result of drainage impedance during a prolonged period (or periods) of heavy rainfall. The profile also yields some mangrove pollen, which consistently increases in representation, thus suggesting that the peat also formed during a long period of rising sea levels or a succession of phases of rising sea levels followed by marine transgressions. Similar thickness coals in the Latrobe valley in Australia have been shown to reflect successive depositional phases on a sequence scale (Holdgate et al., 1995). For the Sarongga coal, however, insufficient data is available on rates of sediment accumulation to determine whether there were similar controls with respect to thick coals in Kalimantan.

The conclusion to be reached from the Sarongga coal is that that the formation of very thick, Tertiary peats probably coincided with periods of prolonged high rainfall, and rising, or intermittently rising sea levels, and not to short-lived periods of stable, but high sea levels, as is the case with Quaternary and Carboniferous peats, and this may indicate the reason why there are parallels between many Carboniferous and Quaternary peats, but seemingly less so with Cenozoic coals.

Very thick, Middle and Late Miocene coals to the northwest of Samarinda in Kalimantan were studied for geochemistry by Widodo et al. (2009). They recorded several biomarkers which reflect the nature of the peat forming vegetation, and these included bicadinene, which is 
thought to be a geochemical derivative of resins from members of the family Dipterocarpaceae (van Aarssen et $a l ., 1990,1994)$. They also used the ratio of diterpenoids $v s$ diterpenoids +triterpenoids as an indicator of the proportion of angiosperms $v s$ gymnosperms within the peat forming vegetation, following Bechtel et al. (2002), and demonstrated that during the Middle Miocene and earliest Late Miocene, gymnosperms were likely to have been major contributors to the peat swamp vegetation, but that they contributed little to later Late Miocene peatswamp vegetation. They interpreted this trend as indicating cooler climates during the Middle and early Late Miocene, in contradiction to global climate trends (Zachos et al., 2001). More realistically, the dominance of gymnosperm indicators in the Middle and early Late Miocene suggests that peats formed at this time were kerapah peats, with Dacrydium and possibly Agathis being important components, but that later Late Miocene peats formed in more basinal peat swamp settings (see below).

\section{Basinal peats}

Palynological analyses show that during the later part of the Early Miocene there was an increase in the representation of taxa typical of modern peat swamps, such as Melanorrhoea (Anacardiaceae), Durio (Bombacaceae), Blumeodendron and Neoscortechinia (Euphorbiaceae), Calophyllum, Garcinia cuspidata type (Guttiferae), and Gonystylus, first brought to attention by Muller (1972). This is thought to reflect the expansion of basinal peats from this time onward. Anderson and Muller (1975) went on to analyse in detail a $1 \mathrm{~m}$ thick coal from Berakas in Brunei to determine whether parallels could be seen between the succession in a Miocene coal and that reported from Holocene peats (Fig. 12). They suggested an age of about 7 million years (Ma) for the Berakas coal, on the basis of the rarity of Florschuetzia trilobata, which is probably an underestimate. It is likely that the rarity of Florschuetzia spp. in this section is due to the freshwater

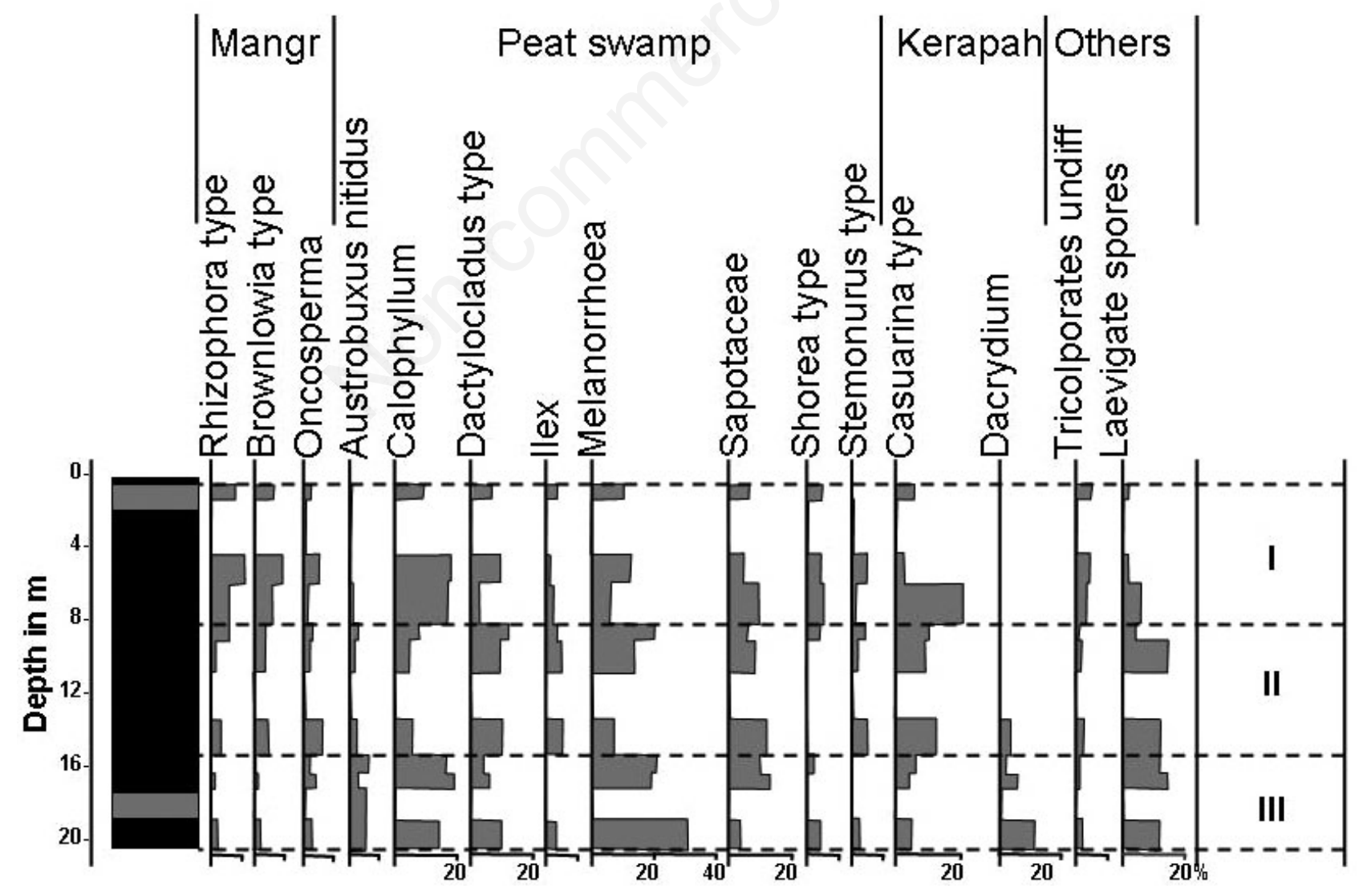

Fig. 11. Palynological analysis of Sarongga coal, Early/Middle Miocene, East Kalimantan [summarised from Demchuck and Moore (1993)]. Lithologies: grey=shale; black $=$ coal. 
facies; the presence of common Stenochlaena areolaris (Blechnaceae), and absence of S. milnei type suggests that the age is more likely to be a little older than $10 \mathrm{Ma}$ (Morley, 1991, 2000), probably latest Middle Miocene.

Anderson and Muller (1975) emphasised that the similarity between the palynomorph spectra from the Berakas coal and the Holocene peat from Marudi suggested a close relationship between the Middle Miocene peat swamp flora and the flora of present day basinal peat swamps. There is, however, a major difference which was not previously brought to attention; the diversity of the peat swamp element in the Berakas section was markedly less than in the Marudi profile (Berakas, 28 pollen types in a count of about 15,000; Marudi, 40 pollen types in a count of about 3000), and bearing in mind that indeterminate pollen types were excluded from consideration, the similarity between the two successions was probably overestimated.

The Berakas coal (Fig. 12) clearly illustrates three separate intervals of peat buildup (A-C), the first being terminated by a phase of apparent disturbance, and subsequent phases being terminated by marine transgression, with the third transgression overriding the peat, and depositing beach sands. Within each of these phases of peat buildup, Anderson and Muller (1975) suggested that the peat-forming vegetation never passed beyond ph. 1, in particular by the common occurrence more or less throughout of Durio pollen. The absence of more advanced phasic communities was also explained by the low representation of Shorea albida [which may have been present in the Middle Miocene, as leaf fragments recorded from Middle Miocene of East Kalimantan, near Samarinda (nannofossil zone NN5) closely resembled $S$. albida (Morley and Morley, 2010)]. The upper part of peat buildup B contains abundant Cephalomappa pollen, and locally reduced pollen of Durio. Cephalomappa beccariana is more typical of deep peat within ph. 1, and also in ph. 2-4. There is a strong possibility that a more advanced stage within the peat swamp catena is represented between 43 and $49 \mathrm{~cm}$.

The different sampling strategies employed for the study of the Berakas by Anderson and Muller (1975), the Sarongga and Nanggulan coals, and the Marudi peat are compared in Fig. 13 by assuming a 1:7 compaction ratio for Cenozoic coals. The comparison provides a guide as to the sampling densities needed in order to differentiate veg-

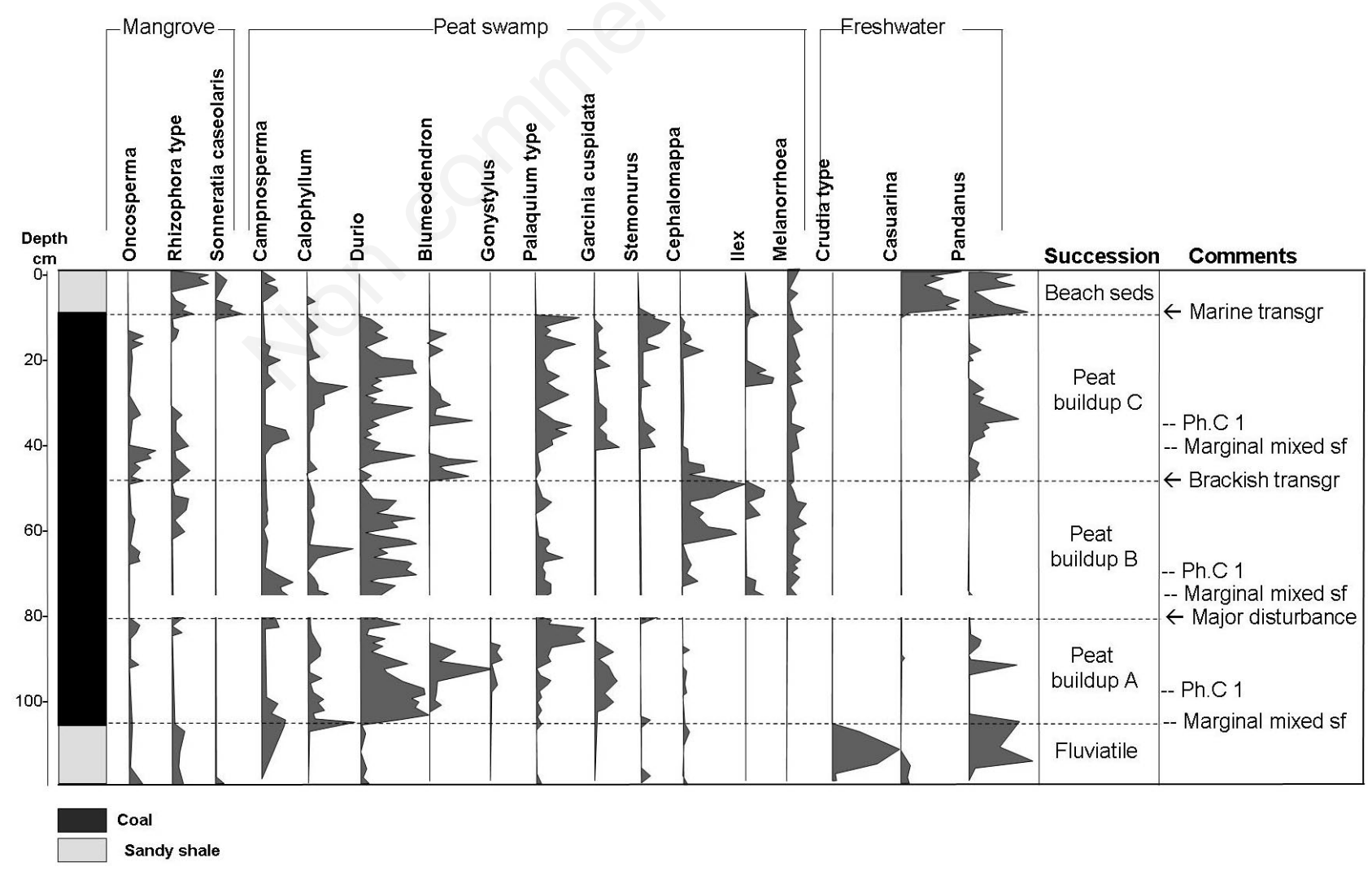

Fig. 12. Summary of palynological analysis of Middle/Late Miocene Berakas coal, Brunei (Anderson and Muller, 1975). Lithologies are to the left of diagram. 
etational successions in sufficient detail to permit the differentiation of ombrogeny. The very closely spaced $1 \mathrm{~cm}$ samples from the Berakas coal (each equivalent to $7 \mathrm{~cm}$ of peat accumulation; Anderson and Muller suggested something less than $1: 10$ ) were sufficient to pick out individual tree generations; the $50 \mathrm{~cm}$ sample spacing in the Marudi peat facilitated the differentiation of phasic communities, whereas the $50 \mathrm{~cm}-2 \mathrm{~m}$ crushed interval samples from Sarongga (equivalent to 3.5-14 m of peat) were sufficient to pick out only the broadest, regional succession.

\section{Rheotrophic peats}

Calamus type pollen is common in many coals within the Early Miocene, but is much less well represented in Middle Miocene and younger coals. In 1972, an Early Miocene shaley coal from the Kerinci area of Sumatra was collected by the author and sent to the late Jan Muller for analysis. This coal also proved to be dominated by Calamus type pollen. (Muller, personal communication), but unfortunately the detailed results of this study were never published. However, based on comparisons with present day swamps, it is likely that the peat which formed the coal accumulated in a rheotrophic swamp setting. Rattan pollen-dominated successions rich in coals were widespread, especially during the Early Miocene, and hence rheotrophic peat-forming swamps could have been widespread at this time. Rattan-dominated swamp successions often occur in sedimentary successions which suggest slight seasonality of climate.

\section{Fern-dominated peats}

Fern spores are often prominent elements in the initial stages of both basinal and kerapah/watershed peat development. Sometimes the basal part of a coal is dominated by spores of the climbing fern Stenochlaena palustris, and it is of note that when peat swamp forests are felled, the initial growth is often of $S$. palustris, prior to the establishment of tree cover. Sometimes other fern spores may

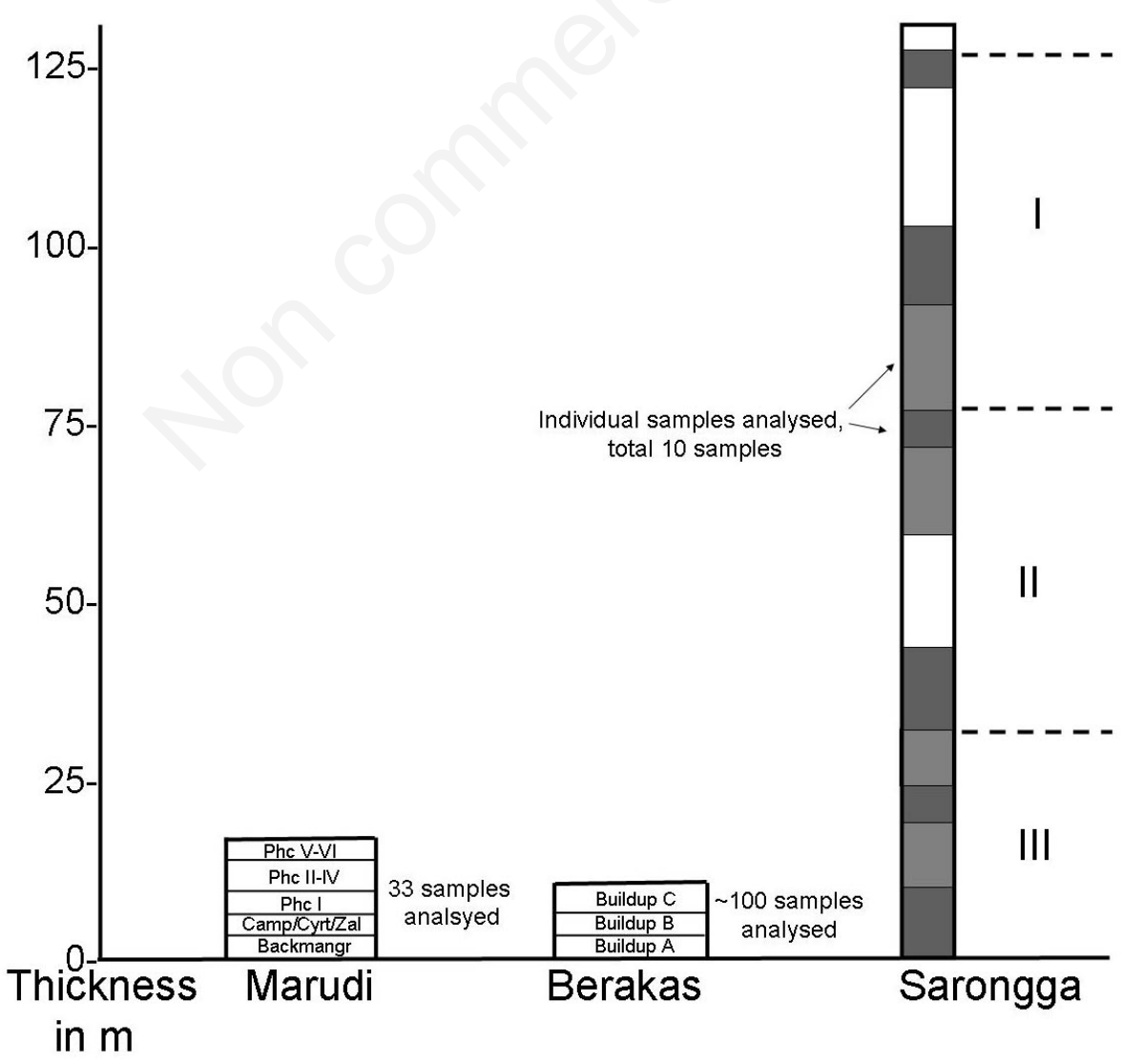

Fig. 13. Estimated decompaction thicknesses for Southeast Asian coals. 
be prominent, either of the Nephrolepis type, or undifferentiated laevigate fern spores. The basal horizon of the Sebangau peat was characterised by abundant fern smooth spores (Morley, 1981a).

\section{Barringtonia peats}

These have been reported from the Early Miocene of the Malay basin, and the Middle Miocene Warukin formation in SE Kalimantan and probably reflect peats which formed under an everwet climate in localities which exhibited extreme seasonal flooding. No present day analogues are known.

\section{Mangrove peats}

Thick, Middle Miocene coals and carbonaceous shales from the Belait formation of Brunei sometimes contain extremely high frequencies of Rhizophora type pollen (Gupta, unpublished report). A profile through a typical section (Fig. 14) shows that the carbonaceous shales accumulated in a very widespread mangrove swamp,

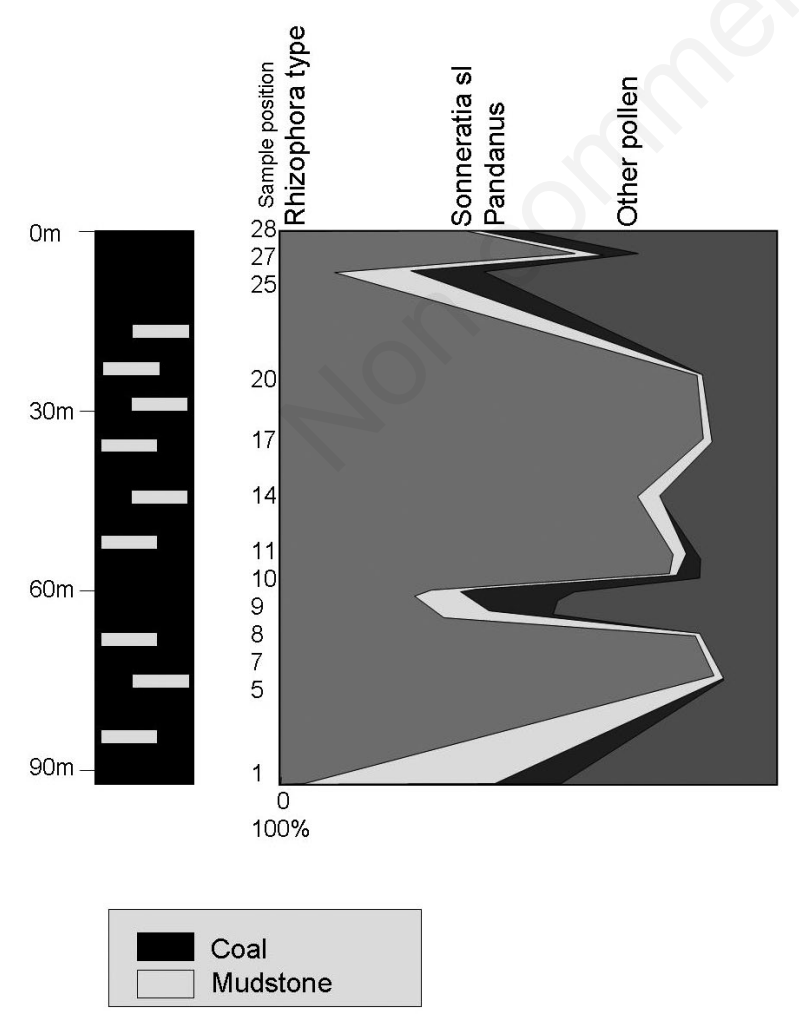

Fig. 14. Summary of palynological analyses of a coal and carbonaceous shale from Subok, Belait formation, Brunei (Gupta, unpublished report). whereas the peats which formed the coals accumulated in a slightly saline backmangrove, or possibly intertidal, but freshwater setting, based on the common occurrence of Sonneratia and Pandanus pollen.

Thick (5 m) and very widespread coals occurred in the Late Miocene of the Malay basin, marking the end of seismic group E. These were analysed palynologically (Shamsudin et al., 2011) and were also shown to be overwhelmingly dominated by Rhizophora type, Sonneratioid and Pandanus pollen, as with the Belait coal analysed by Gupta (unpublished report). The palynological succession showed successive alternations of mangrove pollen and Pandanus, suggesting that the coal is most likely formed from a stacked succession of peats, formed during perhaps five successive sea level oscillations.

Nypa peats have been reported in the Miocene of the Warukin formation (Witts et al., 2011). They reflect periods of peat accumulation in areas of oligotrophic coastal water (devoid of nutrients) within a slightly brackish setting. No present day analogues are known. Brownlowia peats have been reported from the same area, and possibly reflect peat swamp accumulation in a freshwater but intertidal setting. Again, no present day analogues are known.

Coals rich in mangrove pollen have also been reported from limestone-dominated successions (Cole, 1987), for instance, from the Middle to Late Miocene Kais formation in Irian Jaya (Hendardjo and Netherwood, 1986), and similar age limestones from the Banggai-Sula area. Cole (1987) termed these archipelagic mangrove peats. Peats forming on limestones are unknown today in Southeast Asia, but occur on Pacific islands, as noted above, and also are well documented in Florida by Spackman et al. (1966), where they also appear to have formed in a mangrove environment, and clearly provide a close analogue to archipelagic coals.

\section{DISCUSSION}

At the present time, lowland Southeast Asian peats are forming mainly as ombrotrophic, oligotrophic basinal peats and kerapah peats, the latter characterised by the presence of Gymnostoma and Dacrydium as prominent elements of the tree flora. Rheotrophic peats tend to be geographically isolated, and also of restricted occurrence, although there are some extensive rheotrophic peat swamps. Palms, especially rattans, are prominent elements of present day rheotrophic peats. Brackish peats are rare, but were more widespread during the Holocene than today.

During the Cenozoic, the representation of these peat types differed substantially from that of the present day as follows (summarised in Tab. 1): i) during the early Cenozoic, transitional, brackish to freshwater rheotrophic peats were widespread, especially in the Middle to Late Eocene; ii) rheotrophic peats probably developed within the initial stage of infilling of Oligocene grabens, pro- 
vided that the climate was favourable for peat formation. Otherwise, peat development was very limited until the Late Oligocene thermal maximum, during which time kerapah peats formed extensively along the southern coast of Sundaland, and brackish peats with common Florschuetzia trilobata pollen formed along the eastern coast; iii) Kerapah peats were very prominent during the Early and Late Miocene around the basins of the northern Sunda shelf, but seem to have been poorly represented in that area during the Middle Miocene thermal maximum. Many of the very thick coals observed in the Middle Miocene of Kalimantan are probably of this type; iv) basinal peats are probably widely preserved as coals from the Early Mocene onward, but became prominent from the Middle Miocene. Although few have been studied in detail, there is weak evidence for a vegetational catena from the Berakas coal studied by Anderson and Muller (1975), but otherwise no examples of a clear succession comparable to the succession seen in the domed peats of today have yet been reported. However, no thick peats have yet been studied so as to reveal the presence of doming; v) mangrove peats also formed extensively in the Middle and early Late Miocene in the Sunda shelf region. They also developed locally in Eastern Indonesia over carbonates, perhaps in settings analogous to those observed today on carbonates in Florida.

The floristic character of peat-forming vegetation has clearly changed during the course of the Tertiary. Paleocene and Eocene peats were mainly vegetated with palms, and many elements of the Eocene rheotrophic peat swamp floras became extinct during the Oligocene. Eocene peats also bore a rich vegetation of fresh and brackish water palms, which included Nypa, rattans, and extinct palms within the tribe Iguanurinae. Several other peat-swamp trees were also present at this time, such as Ctenolophon, and possibly Durio. Rattans formed conspicuous elements of peat-forming vegetation until the Early Miocene.

Peat-forming vegetation of more modern aspect first became established within the Late Oligocene, initially with Dacrydium and Gymnostoma (indicated by Casuarina type pollen) growing on widespread kerapah type swamps. The typical elements of modern basinal peats such as Blumeodendron, Calophyllum, Combretocarpus, Dactylocladus, Garcinia cuspidata, Neoscortechinia and Melanorrhoea became prominent principally in the Early and Middle Miocene. Greater diversity seen in present day kerapah peats compared to basinal may relate to the much greater geological age of kerapah peats.

Tab. 1. Generalised representation of peat forming environments over time.

\begin{tabular}{|c|c|c|c|c|}
\hline & Basinal peats & Kerapah peats & Rheotrophic peats & Mangrove peats \\
\hline Present/Late Pleistocene & $\begin{array}{l}\text { Widespread after } \\
\text { sea level stabilised }\end{array}$ & $\begin{array}{l}\text { Limited today, widespread } \\
\text { as sea levels rose }\end{array}$ & $\begin{array}{c}\text { Extensive swamps locally, } \\
\text { but mostly small, } \\
\text { with Pandanus, rattans }\end{array}$ & $\begin{array}{l}\text { Rare in Sunda, sometimes } \\
\text { on oceanic islands }\end{array}$ \\
\hline Late Miocene & $\begin{array}{l}\text { Probably widespread } \\
\text { but little-studied }\end{array}$ & $\begin{array}{l}\text { Widespread in } \\
\text { Kalimantan }\end{array}$ & $\begin{array}{l}\text { Pandanus peats associated } \\
\text { with mangrove peats }\end{array}$ & $\begin{array}{c}\text { Thick peats in Malay basin, } \\
\text { insular peats in Papua, } \\
\text { Sulawesi }\end{array}$ \\
\hline Middle Miocene & Widespread across region & $\begin{array}{l}\text { Widespread from Sunda } \\
\text { shelf to South Kalimantan }\end{array}$ & $\begin{array}{l}\text { Rattan peats reduced, } \\
\text { some Barringtonia peats }\end{array}$ & $\begin{array}{c}\text { Extensive in Brunei, } \\
\text { Nypa peats in SE Borneo }\end{array}$ \\
\hline Early Miocene & $\begin{array}{l}\text { Become common in later } \\
\text { Early Miocene }\end{array}$ & $\begin{array}{l}\text { Widespread around inland seas } \\
\text { of N Sunda shelf }\end{array}$ & $\begin{array}{l}\text { Rattan peats widespread, } \\
\text { some Barringtonia peats }\end{array}$ & \\
\hline Late Oligocene & & $\begin{array}{l}\text { Extensive along southern } \\
\text { coast of Sundaland }\end{array}$ & $\begin{array}{c}\text { Rattan peats along southern } \\
\text { Sunda coast }\end{array}$ & $\begin{array}{l}\text { Florschuetzia peats } \\
\text { along eastern coast } \\
\text { of Sundaland }\end{array}$ \\
\hline Early Oligocene & & & $\begin{array}{l}\text { Peat formation rare. Occ. } \\
\text { palm and fern swamps } \\
\text { in C Sumatra }\end{array}$ & \\
\hline Late Eocene & & & $\begin{array}{l}\text { Rattan swamps in Burma. } \\
\text { Palm and Meyeripollis swamp } \\
\text { in Java, Kalimantan }\end{array}$ & $\begin{array}{l}\text { Nypa swamps in Java, } \\
\text { Kalimantan }\end{array}$ \\
\hline Middle Eocene & & & $\begin{array}{l}\text { Palm-dominated swamps } \\
\text { in Java }\end{array}$ & $\begin{array}{l}\text { Nypa/Florschuetzia } \\
\text { swamps in Java }\end{array}$ \\
\hline Paleocene & & & $\begin{array}{l}\text { Palm dominated swamps } \\
\text { in Java sea area }\end{array}$ & \\
\hline
\end{tabular}




\section{CONCLUSIONS}

At the present time, peat swamps are undergoing widespread destruction from timber extraction and land conversion across the region. This review emphasises the antiquity and longevity of peat swamp communities from a deep-time perspective, and especially highlights the importance of kerapah peats as one of the most ancient vegetation types in the region, which, in fact, is given minimal specific consideration from a conservation point of view. The review also emphasises the importance of differentiating rheotrophic from oligotrophic swamps, also rarely taken into consideration by conservationists, and brings to the fore the importance of conserving areas such as the Berbak swamps in Sumatra, and Tasek Bera in the Malay peninsula.

\section{ACKNOWLEDGMENTS}

The author is grateful to the late Jan Muller, for providing detailed results of his unpublished analyses; to Senjavit Gupta for permission to use unpublished results from a coal from Subok, Brunei; to Jon Barton, for permission to report data from his thesis; and to Peter Ashton and Robb Anderson for photos of Seria peat swamps from the 1960s. The authors would also like to thank the organisers of the 2012 FISA conference, Prof. La-orsri Sanoamuang and Dr. Maria K. Hołyńska for inviting us to the Mahasarakam workshop in Thailand, and prompting the rewriting of this paper from an earlier draft, and also to Dr. Kay van Damme for inviting to contribute to the proceedings. Carlos Jamarillo kindly reviewed the manuscript. The late Tim Whitmore and Margaret Collinson kindly provided extremely valuable comments on a very early version of this paper.

\section{REFERENCES}

Allen GP, Laurier D, Thouvenin J, 1979. [Étude sédimentologique du delta de la Mahakam. Notes et Mémoires]. [Book in French]. TOTAL Compagnie française des Pétroles ed., Paris: $156 \mathrm{pp}$.

Anderson JAR, 1963. The flora of the peat swamp forests of Sarawak and Brunei, including a catalogue of all recorded species of flowering plants, ferns and fern allies. Botanic Gardens ed., Singapore: 238 pp.

Anderson JAR, 1964. The structure and development of the peat swamps of Sarawak and Brunei. J. Trop. Geogr. 18:7-16.

Anderson JAR, 1976. Observations on the ecology of five peat swamp forests in Sumatra and Kalimantan. Peat and podsolic soils in Indonesia, p. 45-55. In: Proc. ATA 106 Midterm Seminar, Peat and Podzolic Soils and their Potential for Agriculture in Indonesia.

Anderson JAR, 1983. The tropical peat swamps of western Malesia, p. 181-199. In: A.J.P. Gore (ed.), Ecosystems of the world. Mires, swamp, bog, fen and moor. Elsevier.

Anderson JAR, Muller J, 1975. Palynological study of a holocene peat and a Miocene coal deposit from N.W. Borneo. Rev. Palaeobot. Palyno. 19:291-351.
Andriesse JP, 1974. The characteristics, agricultural potential and reclamation problems of tropical lowland peats in South-east Asia. Royal Tropical Institute ed., Amsterdam: 62 pp.

Anshari G, Kershaw A, van der Kaas S, 2001. A Late Pleistocene and Holocene pollen and charcoal record from peat swamp forest, lake Sentarum wildlife reserve, West Kalimantan, Indonesia. Palaeogeogr. Palaeocl. 171:213-228.

Bartram K, Nugrahaningsih L, 1990. A palynological study of the Sawahlunto formation, Ombilin basin, West Sumatra, p. 123-136. In: Lemigas (ed.), Lemigas Scientific Contributions on Petroleum Science and Technology. Lemigas ed.

Bechtel A, Sachsenhofer RF, Kolcon I, Gratzer R, Otto A, Püttmann W, 2002. Organic geochemistry of the Lower Miocene Oberdorf lignite (Styrian basin, Austria): its relation to petrography, palynology and the palaeoenvironment. Int. J. Coal Geol. 51:31-57.

Brunig EF, 1968. [Der Heidewald von Sarawak und Brunei. Standort und vegetation, Artenbeschreibung und Anhange]. [Book in German]. Max Wiedebusch ed., Hamburg: 484 pp.

Brunig EF, 1974. Ecological studies in Kerangas forests of Sarawak and Brunei. Borneo Literature Bureau for Sarawak Forest Department ed., Kuching: 250 pp.

Brunig EF, 1990. Oligotrophic forested wetlands in Borneo, p. 299-334. In: A.E. Lugo, M. Brinson, and S. Brown (eds.), Ecosystems of the world. 15. Forested wetlands. Elsevier.

Bunning E, 1947. [In den Walden Nordsumatras]. [Book in German]. F. Duemmlers Verlag ed., Bonn: 187 pp.

Caline B, Huang J, 1992. New insights into the recent evolution of the Baram delta from satellite imagery. Bull. Geol. Soc. Malaysia 32:1-13.

Clymo RS, 1987. Rainwater-fed peat as a precursor to coal, p. 17-23. In: A.C. Scott (ed.), Coal and coal-bearing strata: recent advances. Geological Society Publ.

Cole J, 1987. Some fresh/brackish water depositional environments in the SE Asian Tertiary with emphasis on coal-bearing and lacustrine deposits and their source rock potential. Proc. of the $16^{\text {th }}$ Annu. Conv. Indonesian Petroleum Association 1:429-434.

Corner EJH, 1978. The freshwater swamp-forest of South Johore and Singapore. Botanic Gardens ed., Singapore: 266 pp.

Demchuck T, Moore TA, 1993. Palynofloral and organic characteristics of a Miocene bog-forest Kalimantan, Indonesia. Org. Geochem. 20:119-134.

Dommain R, Couwenberg J, Joosten H, 2011. Development and carbon sequestration of tropical peat domes in south-east Asia: links to post-glacial sea-level changes and Holocene climate variability. Quaternary Sci. Rev. 30:999-1010.

Dransfield J, 1974. Notes on the palm flora of Central Sumatra. Reinwardtia 8:519-531.

Dudley-Stamp L, 1925. The vegetation of Burma. From an ecological standpoint. University of Rangoon ed., Rangoon: $65 \mathrm{pp}$.

Eble CF, Gaudy WC, 1990. Palaeoecological interpretation of a middle Pennsylvanian coal bed in the Central Appalachian basin. Int. J. Coal Geol. 16:255-286.

Ellison J, 2009. Wetlands of the Pacific Island region. Wetl. Ecol. Manag. 17:196-206.

Endert FH, 1932. [Het natuurmonument Danau in Bantam]. [Article in Dutch]. Tectona 25:963-987.

Esterle J, Ferm JC, 1994. Spatial variability in modern tropical 
peat deposits from Sarawak, Malaysia and Sumatra, Indonesia: analogues for coal. Int. J. Coal Geol. 26:1-41.

Flenley JR, Morley RJ, Maloney BK, 1972. Investigation of Quaternary vegetational history in Southeast Asia. Natural Environmental Research Council ed., Hull: 59 pp.

Furtado JH, Mori S, 1982. Tasek Bera. The ecology of a freshwater swamp. Junk ed., The Hague: 413 pp.

Gastaldo RA, Allen GP, Huc AY, 1993. Detrital peat formation in the tropical Mahakam river delta, Kalimantan, eastern Borneo: formation, plant composition, and geochemistry. Geol. S. Am. S. 286:107-118.

Gastaldo RA, 2010. Peat or no peat: why do the Rajang and Mahakam deltas differ? Int. J. Coal Geol. 83:162-172.

Gaudy WC, Eble CF, 1990. Relationships among macerals, minerals, miospores and palaeoecology in a column of Redstone coal (Upper Pennsylvanian) from north-central West Virginia (U.S.A.). Int. J. Coal Geol. 15:1-26.

Harley MM, Morley RJ, 1995. Ultrastructural studies of some fossil and extant palm pollen, and the reconstruction of the biogeographical history of the subtribes Iguanurinae and Calaminae. Rev. Palaeobot. Palyno. 85:153-182.

Hendardjo KS, Netherwood RE, 1986. Palaeoenvironment and diagenetic history of the Kais formation, KSBA, Irian Jaya. Proc. of the $15^{\text {th }}$ Annu. Conv. Indonesian Petroleum Association 1:432-438.

Holdgate GR, Kershaw AP, Sluiter IRK, 1995. Sequence stratigraphic analysis and the origins of Tertiary brown coal lithotypes, Latrobe Valley, Gippsland basin, Australia. Int. J. Coal Geol. 28:249-275.

Hope G, Chokkalingam U, Anwar S, 2005. The stratigraphy and fire history of the Kutai peatlands, Kalimantan, Indonesia. Quaternary Res. 64:407-417.

Horton BP, Gibbard PL, Milne GM, Morley RJ, Purintavaragul C, Stargardt JM, 2005. Holocene sea levels and palaeoenvironments. Holocene 15:1199-1221.

Kamaludin H, Yakzan MY, 1997. Interstadial records of the last glacial period at Pantai Remis, Malaysia. J. Quaternary Sci. 12:419-434.

Kershaw AP, Penny D, van der Kaars S, Anshuri G, Thamotherampillai A, 2000. Palaeoecological evidence for vegetation and climate in lowland Southeast Asia at the last glacial maximum. In: I. Metcalfe, J.M.B. Smith, M. Morwood, I. Davidson and K. Hewison (eds.), Floral and faunal migrations and evolution in Australia-Southeast Asia. Balkema.

Koesoemadinata RP, Matasak T, 1981. Stratigraphy and sedimentation, Ombilin basin, Central sumatra, Indonesia, $\mathrm{p}$. 217-249. Proc. of the $10^{\text {th }}$ Annu. Conv. Indonesian Petroleum Association.

Koorders H, 1895. [Die Tropen-Sumpfflaschmoor-Natur der Moore des Productiven Karbons]. [Article in German]. Berlin Jahrb. Geol. Landesanst. 30:389-419.

Lelono EB, Morley RJ, 2011. Oligocene palynological succession from the East Java sea, p. 333-346. In: R. Hall and M. Wilson (eds.), Southeast Asian gateway evolution. Geological Society of London ed.

Morley RJ, 1981a. Development and vegetation dynamics of a lowland ombrogenous swamp in Kalimantan Tengah, Indonesia. J. Biogeogr. 8:383-404.

Morley RJ, 1981b. Palaeoecology of Tasek Bera, a lowland swamp in Pahang, West Malaysia. Singapore J. Trop. Geo. 2:50-56.

Morley RJ, 1982a. A palaeoecological interpretation of a 10000 year pollen record from Danau Padang, Central Sumatra, Indonesia. J. Biogeogr. 9:151-190.

Morley RJ, 1982b. The origin and history of Tasek Bera. In: J.I. Furtado and R.P. Lim (eds.), The ecology of a tropical freshwater swamp, the Tasek Bera, with special reference to biological production. Junk Publ., The Hague.

Morley RJ, 1991. Tertiary stratigraphic palynology in South-East Asia. Current status and new directions. Bull. Geol. Soc. Malaysia 28:1-36.

Morley RJ, 1996. Biostratigraphic characterisation of systems tracts in Tertiary sedimentary basins. Proc. of the Symposium on Sequence Stratigraphy in SE Asia, pp. 49-70.

Morley RJ, 1998. Palynological evidence for Tertiary plant dispersals in the SE Asia region in relation to plate tectonics and climate, p. 177-200. In: R. Hall and J. Holloway (eds.), Biogeography and geological evolution of SE Asia. Bakhuys Publ.

Morley RJ, 2000. Origin and evolution of tropical rain forests. Wiley and Sons, London: $362 \mathrm{pp}$.

Morley RJ, 2006. Cretaceous and Tertiary climate change and the past distribution of megathermal rain forests, p. 1-26. In: M. Bush and J.R. Flenley (eds.), Tropical rainforest responses to climatic change. Praxis-Springer.

Morley RJ, 2012. A review of the Cenozoic palaeoclimate history of Southeast Asia, p. 79-114. In: D. Gower, K. Johnson, J. Richardson, B. Rosen, L. Rüber, and S. Williams (eds.), Biotic evolution and environmental change in Southeast Asia. Cambridge University Press.

Morley RJ, Morley HP, 2010. Neogene climate history of the Makassar straits with emphasis on the Attaka field. Proc. of the $34^{\text {th }}$ Annu. Conv. Indonesian Petroleum Association.

Morley RJ, Swiecicki T, Thuy Thi Pham D, 2011. A sequence stratigraphic framework for the Sunda region, based on integration of biostratigraphic, lithological and seismic data from Nam Con Son basin, Vietnam. Proc. of the $35^{\text {th }}$ Annu. Conv. Indonesian Petroleum Association 1:1175-1196.

Muller J, 1963. Palynological study of Holocene peat in Sarawak, p. 147-156. In: Symp. Ecol. Res. in Humid Tropics Vegetation, Kuching, Malaysia.

Muller J, 1968. Palynology of the pedawan and plateau sandstone formations (Cretaceous-Eocene) in Sarawak. Micropalaeontology 14:1-37.

Muller J, 1972. Palynological evidence for change in geomorphology, climate and vegetation in the Mio-Pliocene of Malesia, p. 6-34. In: P. Ashton and M. Ashton (eds.), The Quaternary era in Malesia. Geography Department, University of Hull ed.

Page SE, Rieley JO, Shotyk W, Weiss D, 1999. Interdependence of peat and vegetation in a tropical peat swamp forest. Philos. T. R. Soc. B 354:1885-1897.

Page SE, Rieley JO, Wüst R, 2006. Lowland tropical peatlands of Southeast Asia, p. 145-172. In: I.P. Martini, A. Martínez Cortizas, and W. Chesworth (eds.), Peatlands: evolution and records of environmental and climate changes. Elsevier.

Pierce BS, Stanton RW, Eble CF, 1991. Facies development in the lower Freeport coal bed, west-central Pennsylvania, U.S.A. Int. J. Coal Geol. 18:17-43. 
Polak E, 1933. [Uber torf und Moor in Niederlandisch Indien]. [Article in German]. Verh. Akad. Wet. Amst. 30:1-84.

Polak B, 1950. Occurence and fertility of tropical peat soils in Indonesia. Proc. $4^{\text {th }}$ Int. Congress on Soil Science 2:183185.Potonie R, 1960. [Sporologie der eozanen Kohle von Kalewa in Burma]. [Article in German]. Senckenberbiana Lethaea 41:451-481.

Rieley JO, Page SE, 1997. Biodiversity and sustainability of tropical peatlands. Samara Publ., Cardigan: 369 pp.

Reimann KU, Thuang A, 1981. Results of palynostratigraphical investigations of the Tertiary sequence in the Chidwin basin/Northwestern Burma. Proc. of the $4^{\text {th }}$ International Palynological Conference, Lucknow (1976-77) 3:380-395.

Rupert LF, Stanton RW, Cecil CB, Eble CF, Dulong FT, 1991. Effects of detrital influx in the Pennsylvania upper freeport peat swamp. Int. J. Coal Geol. 17:95-116.

Sewanando M, 1938. [Het veengebied van Benkalis]. [Article in Dutch]. Tectona 31:99-135.

Shamsudin J, Morley RJ, 2006. Integration of biostratigraphy with seismic for sequence stratigraphic interpretation in the Malay basin, p. 101-102. In: Proc. PGCE Malaysia 2006, Kuala Lumpur.

Shamsudin J, Morley RJ, Mahani M, Salwa SH, 2011. Characterisation of peat forming environments of Miocene coal using biofacies in the Malay basin, Malaysia, paper 14. In: Proc. PGCE Malaysia 2011, Kuala Lumpur.

Sieffermann G, Rieley JO, Fournier M, 1992. The low-land peat swamps of Central Kalimantan (Borneo): a complex and vulnerable ecosystem, p. 1-22. In: Proc. of the International Conference of Geography in the Asian Region, Yogyakarta, Indonesia.

Slik FJW, Shin-Ichiro A, Bastian M, Brearley FQ, Cannon CH, Eichhorn KAO, Fredriksson G, Kuswata K, Laumonier Y, Mansor A, Marjokorpi A, Meijaard E, Morley RJ, Hidetoshi N, Nilus R, Nurtjahya E, Payne J, Permana A, Poulsen AD, Raes N, Soedarsono R, van Schaik C, Sheil D, Sidiyasa K, Suzuki E, van Valkenburg JLCH, Webb CO, Wich S, Tsuyoshi Y, Rahmad Z, Zweifel N, 2010. Soikls on exposed Sunda Shelf shaped biogeographic patterns in the equatorial forests of Southeast Asia. P. Natl. Acad. Sci. USA 108: 12343-12347.

Spackmann W, Dolsen CP, Riegel W, 1966. Phytogenic organic sediments and sedimentary environments in the evergladesmangrove complex. I. Evidence of a transgressing sea and its effects on environments of the shark river area of Southwestern Florida. Palaeontogr. Abt. B 117:135-152.

Supiandi S, 1990. [Endapan gambut Holosen di dataran Pantai Jambi, Kalimantan Selatan dan Brunei: kajian berdasar serbuksari fosil]. [Article in Indonesian]. Geologi Indonesia 13:37-61.

van Aarssen BGK, Cox HC, Hoogendoorn P, de Leeuw JW, 1990. A cadinane bipolymer present in fossil and extant dammar resins as a source for cadinanes and bicadinanes in crude oils from Southeast Asia. Geochim. Cosmochim. Ac. 54:3021-3031.

van Aarssen BGK, de Leeuw JW, Collinson M, Boon JJ, Goth K, 1994. Occurrence of polycadinene in fossil and recent resins. Geochim. Cosmochim. Ac. 58:223-229.

van der Kaars S, Penny D, Tibby J, Fluin J, Dam R, Suparan P,
2001. Late Quaternary palaeoecology, palynology and palaeolimnology of a tropical lowland swamp: Rawa Danau, West Java, Indonesia. Palaeogeogr. Palaeocl. 171:185-212. van Steenis CGGJ, 1934. [Het moerasboschje bij Tjitjadas, Res. Batavia]. [Article in Dutch]. Trop. Nat. 23:105-109.

van Steenis CGGJ, Schippers-Lamertse, 1965. Concise plantgeography of Java, p. 1-72. In: C.A. Backer and B. van den Brink (eds.), Flora of Java. Noordhoff Publ.

Wateley MKG, Jordan GR, 1989. Fan-delta-lacustrine sedimentation and coal development in the Tertiary Ombilin basin, Sumatra, Indonesia, p. 317-332. in: M.K.G. Wateley and K.T. Pickering (eds.), Deltas: sites and traps for fossil fuels. Geological Society Publ.

Whitmore TC, 1975. Tropical rain forests of the Far East. Clarendon Press, Oxford: 282 pp.

Whitmore TC, 1984. A new vegetation map of Malesia at scale 1:5 million, with commentary by T.C.Whitmore. J. Biogeogr. 11:461-471.

Whitmore TC, Burnham CP, 1969. The altitudinal sequence of forests and soils on granite near Kuala Lumpur. Malay Nat. J. 22:99-118.

Widodo Sri, Bechtel A, Komang A, Püttmann W, 2009. Reconstruction of floral changes during deposition of the Miocene Embalut coal from Kutai basin, Mahakam delta, East Kalimantan, Indonesia by use of aromatic hydrocarbon composition and stable carbon isotope ratios of organic matter. Org. Geochem. 40:206-218.

Witts D, Witts D, Hall R, RJ, Boudagher-Fadel MK, 2011. Stratigraphy and sediment provenance, Barito Basin Southeast Kalimantan. Proc. of the 35th Annu. Conv. Indonesian Petroleum Association. Available from: http://searg.rhul.ac. uk/pubs/witts_etal_2011\%20Barito\%20Basin\%20Kalimantan.pdf

Witts D, Hall R, Nichols G, Morley RJ, 2012. A new depositional and provenance model for the Tanjung formation, Barito basin, SE Kalimantan, Indonesia. J. Asian Earth Sci. 56:77-104.

Wüst RAJ, Bustin RM, 2004. Late Pleistocene and Holocene development of the interior peat-accumulating basin of Tasek Bera, peninsula Malaysia. Palaeogeogr. Palaeocl. 211:241-270.

Wüst RAJ, Rieley J, Page S, van der Kaars S, Wei-Ming W, Jacobsen G, Smith A, 2007. Peatland evolution in southeasr Asia during the last 35000 cal years: implications for evaluating their carbon storage potential. In: J.O. Rieley, C.J. Banks and B. Radjagukguk (eds.), Proc. of the International Symposium and Workshop on Tropical Peatland Yogyakarta, 27-29 August 2007.

Yulianto E, Sukapti WS, Rahardjo AT, Noeradi D, Siregar DA, Suparan P, Hirakawa K, 2004. Mangrove shoreline responses to Holocene environmental change, Makassar Strait, Indonesia. Rev. Palaeobot. Palyno. 131:251-268.

Zachos JC, Pagini M, Sloan L, Thomas E, Billups K, 2001. Trends, rhythms and aberrations in global climate 65 Ma to Present. Science 292:686-693.

Zetter R, Hesse M, Frosch-Radivo A, 2001. Early Eocene zonaaperturate pollen grains of the Proxapertites type with affinities to Araceae. Rev. Palaeobot. Palyno. 4:267-279. 